US Army Corps

of Engineers ${ }_{\circledast}$

Engineer Research and

Development Center

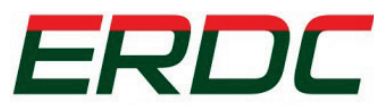

INNOVATIVE SOLUTIONS for a safer, better world

Dredging Operations and Environmental Research Program

\title{
Evaluation Tests of Select Fuel Additives for Potential Use in U.S. Army Corps of Engineers Diesel Engines
}

Michael Tubman and Timothy Welp

July 2016

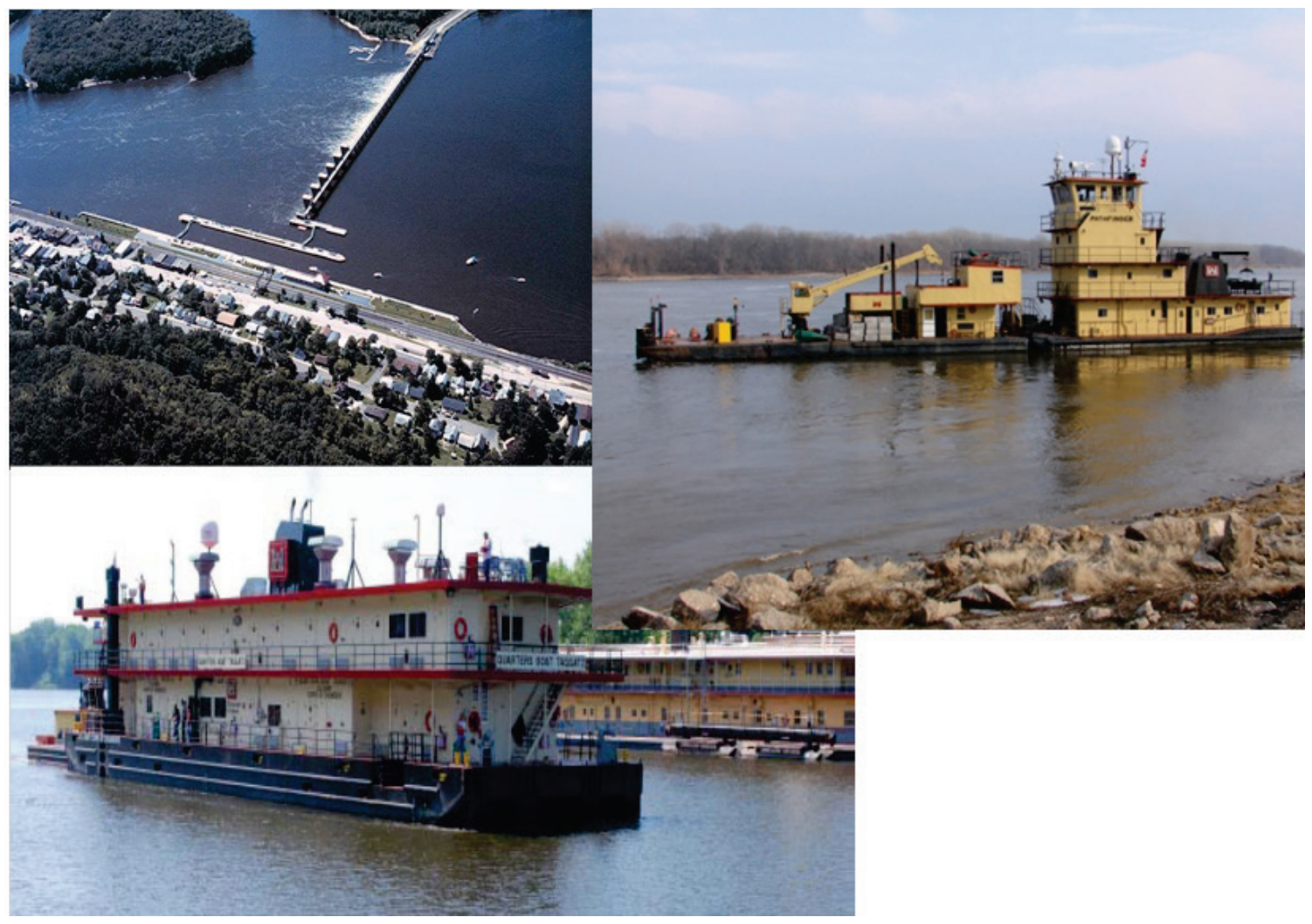


The U.S. Army Engineer Research and Development Center (ERDC) solves the nation's toughest engineering and environmental challenges. ERDC develops innovative solutions in civil and military engineering, geospatial sciences, water resources, and environmental sciences for the Army, the Department of Defense, civilian agencies, and our nation's public good. Find out more at www.erdc.usace.army.mil.

To search for other technical reports published by ERDC, visit the ERDC online library at http://acwc.sdp.sirsi.net/client/default. 


\section{Evaluation Tests of Select Fuel Additives for Potential Use in U.S. Army Corps of Engineers Diesel Engines}

Michael Tubman and Timothy Welp

Coastal and Hydraulics Laboratory

U.S. Army Engineer Research and Development Center

3909 Halls Ferry Road

Vicksburg, MS 39180-6199

Final report

Approved for public release; distribution is unlimited.

Prepared for U.S. Army Corps of Engineers

Washington, DC 20314-1000

Under Work Unit 456009, "Feasibility of Using Diesel Fuel Additives" 


\section{Abstract}

The U.S. Army Corps of Engineers (USACE) has approximately 2,300 floating plant assets that consist of barges, tow boats, floating cranes, survey boats, patrol boats, and fleet dredges that have diesel engines. Under the Dredging Operations and Environmental Research (DOER) program, diesel fuel additives were tested to evaluate their potential for reducing diesel fuel consumption and cost.

Four fuel additives were tested to evaluate their potential for reducing diesel fuel consumption and cost:

- An ethanol injection system

- Envirofuels Diesel Fuel Catalyst

- DurAlt Fuel Conditioner

- Lucas Fuel Treatment.

Fuel usage was measured while using the additives with diesel fuel (candidate tests) and compared to fuel usage under the same conditions while using only standard diesel fuel (baseline tests). The evaluations were conducted in the field under actual, in-use operating conditions. The results are applicable to the host engines and operating conditions, but similar results can be expected for similar engine families, year of manufacture, and operating regimes. While the Envirofuels, DurAlt, and Lucas additives showed limited fuel reduction in select operation conditions, only the ethanol injection system consistently showed potential to reduce diesel fuel consumption, which may be due to its higher injection volume.

DISCLAIMER: The contents of this report are not to be used for advertising, publication, or promotional purposes. Citation of trade names does not constitute an official endorsement or approval of the use of such commercial products. All product names and trademarks cited are the property of their respective owners. The findings of this report are not to be construed as an official Department of the Army position unless so designated by other authorized documents. 


\section{Contents}

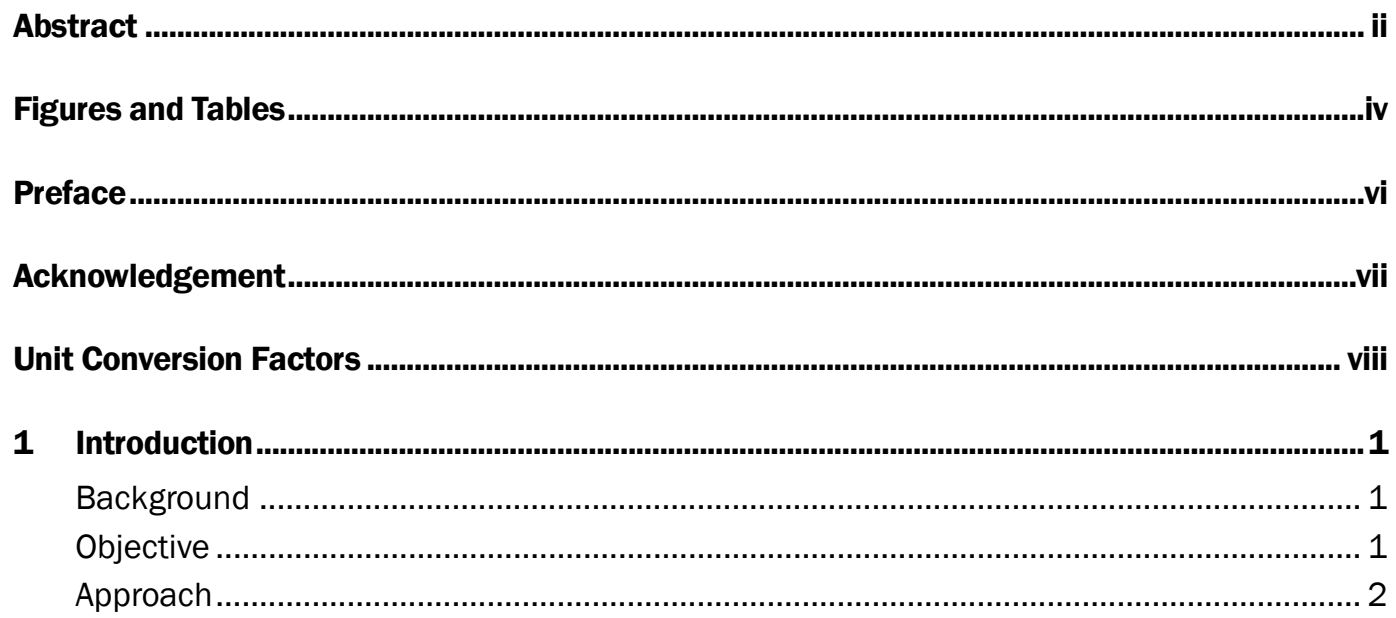

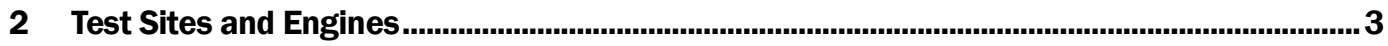

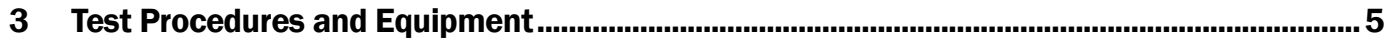

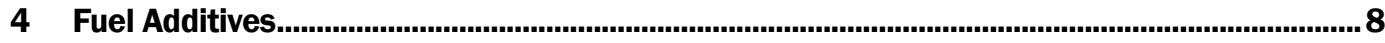

5 Test Results...........................................................................................................................11

Lock and Dam No. 4 ......................................................................................... 11

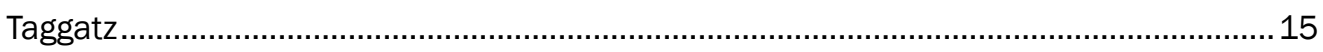

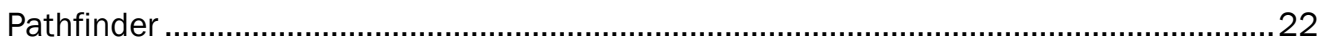

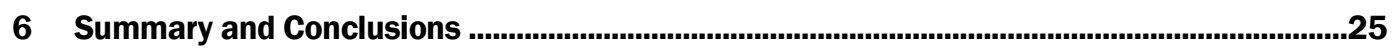

References .................................................................................................................................27

Report Documentation Page 


\section{Figures and Tables}

\section{Figures}

Figure 1. The quarters boat Taggatz............................................................................................

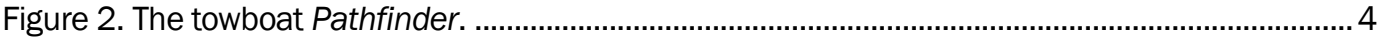

Figure 3. Lock and Dam No. 4 load-bank test results, 50\% load....................................................12

Figure 4. Lock and Dam No. 4 load-bank test results, 75\% load.........................................................12

Figure 5. Lock and Dam No. 4 load-bank test results, 90\% load...................................................13

Figure 6. Lock and Dam No. 4 BTU input and engine output. ..........................................................14

Figure 7. Taggatz port generator baseline and candidate BSFC, 50\% load......................................17

Figure 8. Taggatz port generator baseline and candidate BSFC, 75\% load. ......................................17

Figure 9. Taggatz port generator baseline and candidate BSFC, 85\% load. ....................................18

Figure 10. Taggatz starboard generator and candidate baseline BSFC, 25\% load...........................19

Figure 11. Taggatz starboard generator baseline BSFC, 50\% load. ..................................................20

Figure 12. Taggatz starboard generator baseline BSFC, 75\% load. ................................................20

Figure 13. Taggatz starboard generator baseline BSFC, 85\% load. ................................................21

Figure 14. Pathfinder bollard push test results at different loads. ....................................................22

Figure 15. Duty-cycle test results at different loads. .......................................................................24

\section{Tables}

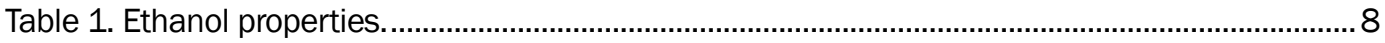

Table 2. Additives (DFC) and fuel amounts during the degeening period..........................................

Table 3. DFC properties. .............................................................................................................

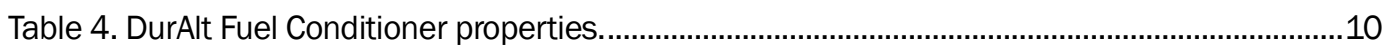

Table 5. Lucas Fuel Treatment additive properties......................................................................10

Table 6. Additives and fuel for break-in periods and testing. ...........................................................10

Table 7. Lock and Dam No. 4 load-bank test results, 50\% load........................................................11

Table 8. Lock and Dam No. 4 load-bank test results, 75\% load. .........................................................11

Table 9. Lock and Dam No. 4 load-bank test results, 90\% load. ......................................................12

Table 10. Lock and Dam No. 4 estimated $\mathrm{CO}_{2}$ emission differences.................................................14

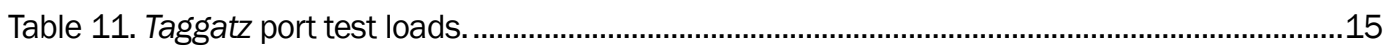

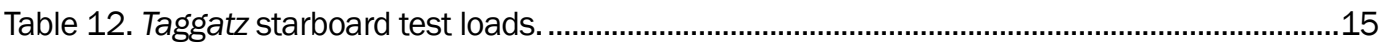

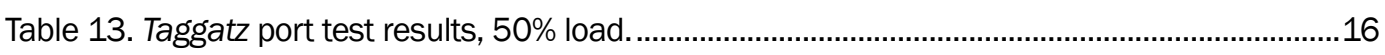

Table 14. Taggatz port test results, 75\% load. .......................................................................................16

Table 15. Taggatz port test results, 85\% load. .................................................................................16

Table 16. Taggatz starboard test results, 25\% load. ......................................................................18

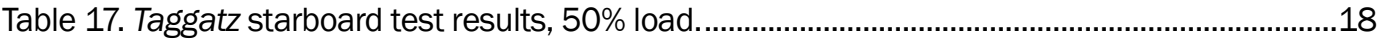

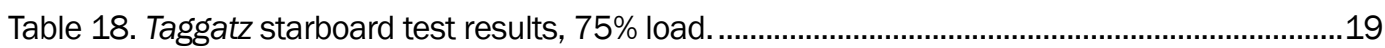




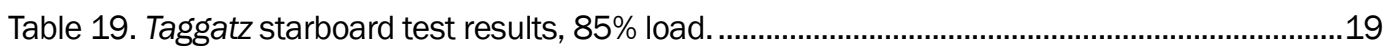

Table 20. Pathfinder bollard-push baseline and candidate fuel consumption changes. ..................23

Table 21. Pathfinder duty-cycle baseline and candidate fuel consumption changes.......................23 


\section{Preface}

This study was conducted for the Headquarters, U.S. Army Corps of Engineers (HQUSACE) under the Dredging Operations and Environmental Research (DOER) Program, Work Unit 456009, "Feasibility of Using Biodiesel Additives." The technical monitor was Dr. Todd Bridges (CEERDEM-D).

The work was performed by the Coastal Engineering Branch of the Navigation Division (CEERD-N), U.S. Army Engineer Research and Development Center, Coastal and Hydraulics Laboratory (ERDC-CHL). At the time of publication, Tanya Beck was Chief, CEERD-HN-C; Dr. Jackie Pettway was Chief, CEERD-HN; and Jeffery Lillycrop, CEERD-HT, was the Technical Director for Navigation. The Director of ERDC-CHL was José E. Sánchez.

This effort was supported by the by USACE Dredging Operations and Environmental Research (DOER) program managed at the U.S. Army Engineer Research and Development Center (ERDC) by Dr. Todd Bridges, Environmental Laboratory (EL). The study was performed in conjunction with the Southern Research Institute, Durham, NC. Southern personnel included Tim Hansen (Green House Gas Center Director), Bill Chatterton (Project Manager), William Crews (Senior Project Leader), and Eric Ringler (Quality Assurance Manager). USACE staff managed all vessel operations and scheduling, managed the purchase and implementation of the fuel additives in accordance with manufacturer specifications, and managed the consistent fuel supplies for the test period. Southern Research Institute managed the test campaign, including test strategy development and documentation, coordination and execution of all field testing, and data validation, analysis, quality assurance and quality control (QA/QC), and reporting.

At the time of publication of this report, the Commander of ERDC was COL Bryan S. Green, and the Director was Dr. Jeffery P. Holland. 


\section{Acknowledgement}

This report was sponsored by the USACE DOER program

(http://el.erdc.usace.army.mil/dots/doer/doer.html). This study would not have been possible without the participation, innovation, and dedication of personnel from the U.S Army Engineer Districts St. Louis (MVS) and St. Paul (MVP). MVS personnel included Lance Engle (Project Manager) and crew of the Pathfinder: Terry Bequette (Skipper), Brett Leavitt, Larry Baltzell (Nub), Mike Morgan (Spike), and Tom Brace. MVP personnel at the Fountain City Service Base included Greg Frankosky (Chief Physical Support Branch), James Maybach (Civil Engineer), Jake Bernhardt (Chief Engineer), and Bobbie Davis (Operator Equipment Repairman, Lock and Dam 4). 


\section{Unit Conversion Factors}

Non-SI units of measurement in this report can be converted to SI (metric) units as follows:

\begin{tabular}{|l|c|l|}
\hline Multiply & By & To Obtain \\
\hline feet & 0.3048 & meters \\
\hline pound-mass per cubic foot & 16.0185 & grams per cubic centimeter \\
\hline pound-force per square inch & 47.8803 & Pascals \\
\hline Grams per cubic centimeter $\left(\mathrm{g} / \mathrm{cm}^{3}\right)$ can be converted to grams per liter $(\mathrm{g} / \mathrm{L})$ by multiplying by 1000. \\
\hline
\end{tabular}




\section{Introduction}

\section{Background}

The U.S. Army Corps of Engineers (USACE) has approximately 2,300 floating plant assets that consist of barges, tow boats, floating cranes, survey boats, patrol boats, and fleet dredges that have diesel engines. The fiscal year 2010 diesel fuel consumption for the floating plant assets was approximately 8.29 million gallons. In addition, there are other uses of diesel engines within the USACE. Providing backup generator power at locks and dams is an example. On 5 October 2009, Executive Order 13514 was issued by President Obama (Office of the Press Secretary 2009) that requires Federal agencies to develop a strategic sustainability performance plan (SSPP) to reduce energy consumption and greenhouse gas emissions, increase agency use of renewable energy, and reduce the use of fossil fuels. For USACE floating plant, one of the main strategies of the USACE SSPP is reducing diesel fuel consumption, and a potential way to accomplish that is to use additives that are proven to reduce regular petroleum-derived diesel consumption.

Under the Dredging Operations and Environmental Research (DOER) program, the following diesel fuel additives were tested to evaluate their potential for reducing diesel fuel consumption (and reducing reliance on fossil fuels and cost:

- An ethanol injection system

- Envirofuels Diesel Fuel Catalyst

- DurAlt Fuel Conditioner

- Lucas Fuel Treatment.

These four technologies were selected from candidates proposed by various districts and subsequently tested on some of the diesel plant of those respective districts.

\section{Objective}

The objective of this study was to evaluate various fuel additives to determine their potential for reducing diesel fuel consumption. 


\section{Approach}

Performance evaluations were conducted on diesel generator sets at the USACE Lock and Dam No. 4 Service Base in Alma, WI, the quarters boat Taggatz located near Wabasha, MN, and the towboat Pathfinder located in Saint Louis, MO. The evaluations were conducted in the field under actual, in-use operating conditions. The results are applicable to the host engines and operating conditions, but similar results can be expected for similar engine families, year of manufacture, and operating regimes.

Development of the test strategy, coordination, and execution of the field testing, data validation, data analysis, quality assurance and control, and reporting was managed by Southern Research Institute's Advanced Energy and Transportation Technologies Department, Durham, NC (referred to hereafter as Southern). Much of this report was compiled from Southern's test reports (Southern 2009, 2010). The testing concept and approach were based partly on Generic In-Use Protocol for Non-road Equipment (Richards and Haggis 2007) developed by the Southern Research Institute for the New York State Energy Research and Development Authority. The generic protocol provides overall test campaign designs, procedures for developing duty cycles, instrument specifications, step-by-step test procedures, and analytical techniques. Site-specific protocols were written to provide information about the individual test sites, nonroad diesel equipment and other details unique to the testing.

The general procedure for calculating fuel consumption was the following:

1. Download the data in Excel format.

2. Subtract the fuel return flow from the fuel supply flow.

3. Calculate the average pounds per hour fuel usage for each run period.

4. Chart the fuel usage throughout the test period and look for abnormalities (such as spikes caused by air bubbles in the meters).

5. Download the torque data in Excel format and sum the torque from each shaft.

6. Time-align the power/torque data with the fuel data.

7. Perform calculations of averages and standard deviations over the test period.

8. Compute the mean gal/bhp-hr over the test.

9. Determine the difference between the baseline test and the candidate (additive) test.

10. Determine the statistical significance of the differences between the baseline and additive performance and calculate the $95 \%$ confidence interval on the difference. 


\section{Test Sites and Engines}

Lock and Dam No. 4 is located near Alma, WI, and Kellogg, MN, on the upper Mississippi River, positioned approximately at river mile 752.8. It was constructed and placed in operation in May 1935. Its last major rehabilitation was from 1988 to 1994. The dam consists of a concrete structure $1367 \mathrm{ft}$ long with six roller gates, 22 retainer gates, and an earth embankment $5400 \mathrm{ft}$ long. The lock is $110 \mathrm{ft}$ wide by $600 \mathrm{ft}$ long.

The alternative power system at the lock uses a Cummins NTA855-G2 inline 6-cylinder engine with a rated brake horsepower (bhp) of 466 at 1800 revolutions per minute (rpm) and a displacement of $855 \mathrm{cu}$ in. Manufactured in 1990, it has only $400 \mathrm{hr}$ of service. It is connected to an Onan Generator, Model \#30oDFCB36975E with a $350 \mathrm{~kW}$ output.

The Taggatz is a 160 (length) x 40 (beam) x 11.5 (draft) ft quarters boat (Figure 1). It operates in the upper Mississippi River out of the St. Paul, MN, USACE service base. The engines for the testing are part of the two generator sets onboard. They are Komatsu SA6D140-1 engines rated $500 \mathrm{bhp}$ at $1800 \mathrm{rpm}$ and displacements of $855 \mathrm{cu}$ in. They were at early life with just under $2000 \mathrm{hr}$ of use. Both engines were coupled to Northern Lights generators, Model \#M6140AL2-330KW with $330 \mathrm{~kW}$ output.

Figure 1. The quarters boat Taggatz.

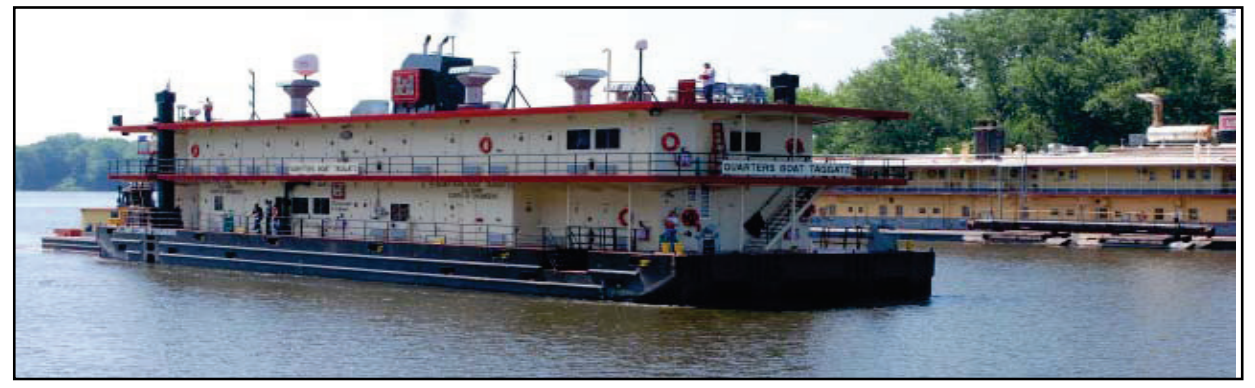

The Pathfinder is a 75 (length) x 30 (beam) x 8.5 (draft) ft twin-screw towboat that displaces 210 tons (Figure 2). It also operates in the upper Mississippi River out of the St. Paul, MN, USACE service base. It is powered by two Caterpillar 3412CDITA engines rated $671 \mathrm{bhp}$ at $1800 \mathrm{rpm}$. The use on the port engine was $3,302 \mathrm{hr}$ since a rebuild in 2007 , and $10,696 \mathrm{hr}$ on the starboard engine since a 2006 rebuild. After the port engine rebuild, the dynamometer specifications indicated that it 
would produce a maximum of $664 \mathrm{bhp}$ at $1845 \mathrm{rpm}$. Both engines have after-coolers and water-cooled turbochargers and are coupled to twin-disc MG-520 transmission drives with 5:1 gear reduction ratios. The shifting is controlled by a pneumatic system manufactured by WABCO Logic Master, which also links the pilot control house to the regulator and the main engine throttles and the clutch. The propeller shafts are connected to the rear of the transmission and travel through the hull and are supported by Johnson Duramax bearings. The shafts are made of Aquamet 15 stainless steel and are $5 \mathrm{in}$. in diameter and $20.75 \mathrm{ft}$ in length.

Figure 2. The towboat Pathfinder.

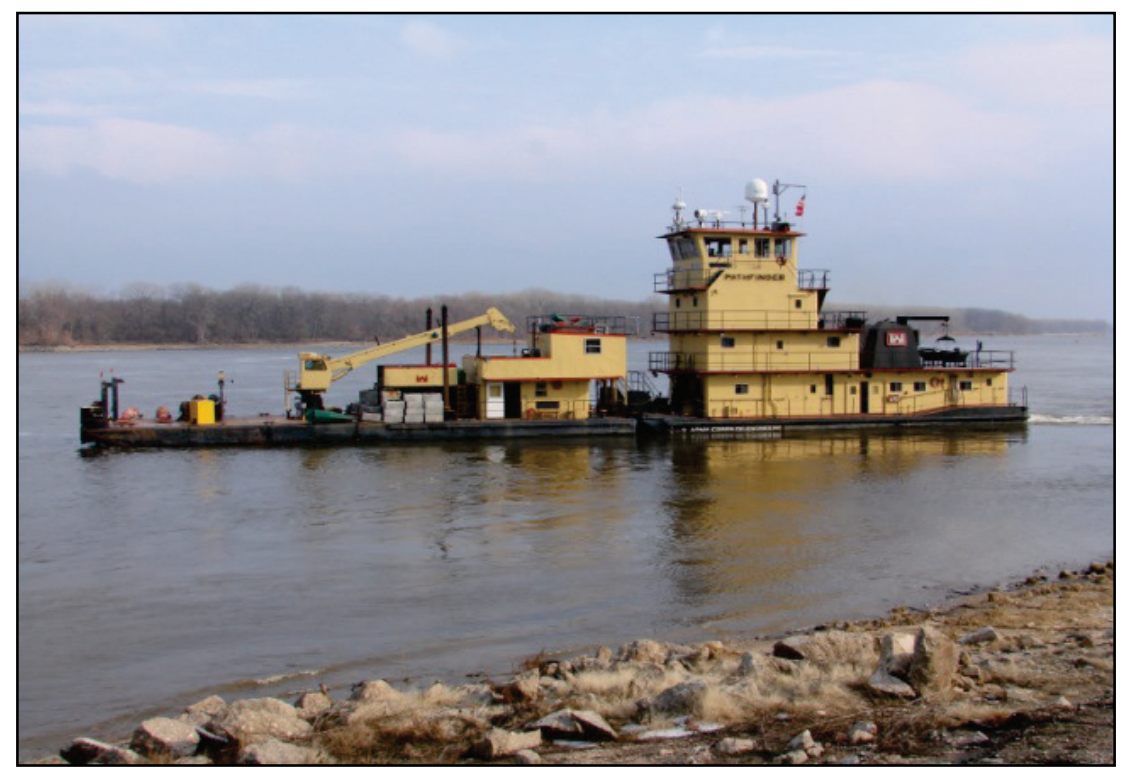




\section{Test Procedures and Equipment}

Duty cycles are detailed descriptions of equipment maneuvers observed during testing. Equipment maneuvers may be described as individual events. For the engines coupled to the generators, events are idle, low, mid-range, and high generator loading. For the Pathfinder, events are backing, travel forward, turning, docking, etc. Composite events consist of a combination of individual events over varying time periods. The Pathfinder, for example, may combine a multiple of simple events such as slight forward travel with a reverse load on the other engine to turn while maintaining both engines at a constant speed for long intervals. A simple duty cycle is an arbitrary arrangement of single or composite events of specified duration (from 15 minutes to $1 \mathrm{hr}$ to allow a reasonable number of test runs during a typical day) under controlled conditions that is representative of a typical work activity task. Simple cycles need to be repeatable as determined by the appropriate cycle criteria.

For the Lock and Dam No. 4 and the Taggatz engine-generator sets, simple duty-cycle testing consisted of a series of specified-generator kilowatt loads with the diesel engines running at $1800 \mathrm{rpm}$. The design generator loads were $25 \%, 50 \%, 75 \%$, and $90 \%$ for the Lock and Dam No. 4 generator and $25 \%, 50 \%, 75 \%$, and $85 \%$ for the Taggatz generators. The tests at each load were designed to last 20 minutes after a stabilization period. However, due to cooling restrictions on the Taggatz at the higher loads, the testing was shortened to 7 minutes for the $75 \%$ load and 3 minutes for the $85 \%$ load.

Simple duty-cycle testing for the Pathfinder was based on the "Guidelines for Bollard Pull Test Procedure" (American Bureau of Shipping 2006) and Surface Vehicle Recommended Practice, Joint TMC/SAE Fuel Consumption Test Procedure - Type II (SAE International 1986). The bollard-push duty cycles test design specified engine powers of idle (engine speed of $630 \mathrm{rpm}$ with reduction gear in forward-shaft speed, $125 \mathrm{rpm}$ ), 25\% (1132 rpm), 50\% (1425 rpm), 75\% (1630 rpm), and 100\% while pushing against a rock wall. It was found that the Pathfinder starboard engine could not be operated at $100 \%$ due to propeller cavitations, so the test design was modified to load the engines at $79.4 \%$ (1660 rpm) in place of the $100 \%$ load test. The push tests were conducted at (closed) Lock 27 where the water 
depth was approximately $25 \mathrm{ft}$, exceeding the ideal minimum depth2.5 times the propeller diameter- under the prop by approximately $6.5 \mathrm{ft}$, and there was negligible current. For each test condition, the engines were run for 30 minutes after they stabilized. Each test was repeated four times. Analysis determined that the repeatability of engine speed and power for an event series, and resulting confidence intervals, varied because of miscellaneous debris in the water below the vessel which could wrap around the propeller during the testing. This variable, for example, caused significant nonuniformity in loads. Therefore, the data was divided into segments of repeatable loads observed during the bollard testing.

Composite-events test design for the Pathfinder specified a series of in-use engine power conditions while operating in a canal with very little current. However, it was found that the repeatability of engine speed and power for an event series, and resulting confidence intervals, varied because of unknowns attached to the Pathfinder propeller during the testing. As a result, only segments of the composite-events data, representing stable operation of the engine and consistent loading at each load level while transiting up and down the canal, were utilized for data analysis. While in transit, propeller cavitations were not a problem, and the analyzed data segments were for engine loads of 25\% (1132 rpm), 50\% (1425 rpm), 75\% (1630 rpm), and 100\% (1800 rpm).

Performance of the additives was evaluated by determining the differences between baseline (no additive) and candidate (with additive) brake specific fuel consumption (BSFC) for each test condition. BSFC is the rate of fuel consumption divided by the power produced. For the enginegenerator sets, it is given as pounds of fuel per kilowatt per hour $(\mathrm{lb} / \mathrm{kWh})$, and for the Pathfinder as pounds of fuel per brake horse power per hour (lb/bhp-hr).

Coriolis meters installed in the diesel engines' fuel supply and return lines measured the fuel mass flow rate. Fuel consumption is the difference between the supply and return fuel rates. Technicians secured the meters to engine room supports with mounting assemblies to isolate them from engine vibration. The return meter was installed vertically with the flow moving from the bottom to top to quickly remove any bubbles in the fuel that may have formed due to excess injector pump temperatures. A ball valve was installed at the discharge of the flow meter to minimize air bubbles in the coriolis tube. Once the meters were installed, test personnel 
ensured that the engines ran properly. Fuel from the return meter was briefly diverted into a transparent hose or a bucket to verify that the flow was not aerated. Prior to commencing testing, operators stopped all engines and technicians completed zero flow checks to the fuel-filled meters per the manufacturer's specifications.

For the Lock and Dam No. 4 and the Taggatz engine-generator sets, an ION 7600 power meter was used to gather electrical power and energy data from the generator sets. Voltage lines for the power meter were connected directly to the lines going to the load bank, and electrical current data was collected from a set of 400:1 current transformers that were also installed on the load-bank lines. The ION meter calculates electrical power, power quality, and energy data from these connections. A pulse signal was sent from the ION meter to the data logger for every 300 Wh of electrical energy generated to verify consumption by the load bank.

For the Pathfinder, a Binsfield TorqueTrack 10K (TT10K) telemetry system with strain gauges bonded to each propeller shaft was used to measure engine-specific power. Shaft revolutions were measured by a Binsfield rpm module with magnetic sensors. The torque sensor consists of a strain gauge permanently bonded to the drive shaft and a batterypowered transmitter. Test personnel attached the transmitter and its 9 -volt battery back to the shaft during the monitoring periods. Shaft diameter and material were inputs to the power calculations.

The shaft revolutions sensor was mounted on an adjustable magnetic base that was attached to a steel plate below the propeller shaft. Two permanent magnets were attached to the shaft. An acquisition module converted the analog and pulse signals to RS-232 to allow communication with the data logging computer. One-second $(1 \mathrm{~Hz})$ in-use fuel consumption, torque, shaft $\mathrm{rpm}$, and power production data were logged during the tests. 


\section{Fuel Additives}

At Lock and Dam No. 4, an alcohol injection system designed by Austin Renewable Fuels was installed on the generator engine. The injection system claims a boost in diesel performance, improvements in fuel economy, and a reduction in emissions. It is designed to deliver a 50/50 ethanol and water mixture to the engine's intake system after the turbo. Its major components consist of a controlled pump and three injection nozzles that were installed in the engines' intake manifolds. The typical maximum injection rate for the generator engine at the Lock and Dam No.4 was approximately 6 gallons per hour. The ethanol alcohol properties are listed in Table 1.

Table 1. Ethanol properties.

\begin{tabular}{|l|l|}
\hline Appearance & Clear liquid \\
\hline Odor & Sweetish, pleasant \\
\hline Specific gravity at & $0.875 @ 60^{\circ} \mathrm{F}$ \\
\hline Density & $0.801 \mathrm{~g} / \mathrm{cm}^{3} @ 60^{\circ} \mathrm{F}$ \\
\hline Flashpoint (t.c.c.) & $55.4^{\circ} \mathrm{F}$ \\
\hline Boiling range & $78.1^{\circ} \mathrm{F}$ \\
\hline Water content & $<0.5 \%$ \\
\hline
\end{tabular}

A diesel fuel catalyst (DFC) produced by Envirofuels was tested on the Taggatz. The Envirofuels DFC claims to provide improvements in fuel economy by creating a catalytic reaction that optimizes the heat release rate of the fuel which leads to an increase in power, reduced emissions, and a decrease in fuel consumption. It is also stated to create a nonaccumulative surface conversion which forms through chemisorptions of the inorganic polymer complex into the surface of ferrous and nonferrous metals. The polymer complex is said to passivate the surface, improving reflectivity and reducing oxygen reactivity, which results in more complete combustion.

The DFC was blended with the vessel's number one diesel and required a minimum degreening period ${ }^{1}$ of $300 \mathrm{hr}$ per engine before candidate testing would be able to measure its effects. After the baseline tests were

\footnotetext{
${ }^{1} \mathrm{~A}$ degreening period is the amount of time required to obtain a stable catalyst prior to assessing its performance characteristics.
} 
completed, the onboard fuel tanks were filled with diesel fuel, and the DFC was added to produce the recommended ratio of 625:1 by volume for the initial passivation and degreening period. Before the additive testing began, the recommended ratio of 1250:1 was run in the engines for more than a month (only a 7-day period was required by the additive manufacturer). Table 2 lists the fuel and additive amounts during the degreening period. Table 3 lists the DFC properties.

Table 2. Additives (DFC) and fuel amounts during the degeening period.

\begin{tabular}{|c|c|c|c|}
\hline Date & Fuel (gallons) & DFC (gallons) & Ratio \\
\hline $8 / 3 / 10$ & 3458 & 5.5 & $629: 1$ \\
\hline $8 / 9 / 10$ & 2450 & 3.75 & $653: 1$ \\
\hline $8 / 23 / 10$ & 2302 & 3.75 & $614: 1$ \\
\hline $8 / 31 / 10$ & 2520 & 4.0 & $630: 1$ \\
\hline $9 / 8 / 10$ & 2650 & 2.0 & $1325: 1$ \\
\hline $9 / 18 / 10$ & 2618 & 2.0 & $1309: 1$ \\
\hline $9 / 25 / 10$ & 2260 & 1.8 & $1256: 1$ \\
\hline
\end{tabular}

Table 3. DFC properties.

\begin{tabular}{|l|l|}
\hline Appearance & Translucent reddish liquid \\
\hline Specific gravity at & $0.85 @ 60^{\circ} \mathrm{F}$ \\
\hline Density & N/A @ 60 ${ }^{\circ} \mathrm{F}$ \\
\hline Flashpoint (COC) & $>212^{\circ} \mathrm{F}$ \\
\hline Viscosity @ $212^{\circ} \mathrm{F}$ & $4.4-5.7 \mathrm{cSt}$ \\
\hline API Gravity or Density & N/A \\
\hline
\end{tabular}

Two additive technologies were selected for Pathfinder testing. The DurAlt fuel additive claims to boost diesel performance by decreasing the engine's requirement for cetane level, resulting in improved fuel economy of 10\% to 20\%. It also claims to lubricate and clean injectors and reduce emissions. The recommended dosage for the DurAlt fuel additive (as provided by the manufacturer) is $1 \mathrm{oz}$ per 23 gallons of diesel fuel. The physical properties of DurAlt fuel saver are listed in Table 4.

The Lucas Fuel Treatment additive produced by Lucas Oil Products, Inc. claims to provide improvements in fuel economy and has additives with high detergents for cleaning the fuel system and combustion chamber. The recommended dosage for the Lucas additive (as provided by the manufacturer) is $32 \mathrm{oz}$ (1 quart)/946 ml per 100 gallons of fuel. The physical properties of the Lucas fuel additive are listed in Table 5. 
Table 4. DurAlt Fuel Conditioner properties.

\begin{tabular}{|l|l|}
\hline Appearance & Translucent, amber liquid \\
\hline Odor & Sweetish, distinctive \\
\hline Specific Gravity at & $0.875 @ 60^{\circ} \mathrm{F}$ \\
\hline Density & $7.33 @ 60^{\circ} \mathrm{F}$ \\
\hline Flashpoint (t.c.c) & $150^{\circ} \mathrm{F}$ \\
\hline Boiling Range & $220-600^{\circ} \mathrm{F}$ \\
\hline Water Content & $<0.5 \%$ \\
\hline
\end{tabular}

Table 5. Lucas Fuel Treatment additive properties.

\begin{tabular}{|l|l|}
\hline Appearance & Translucent, yellow liquid \\
\hline Specific Gravity at & $0.8961 @ 60^{\circ} \mathrm{F}$ \\
\hline Density & $7.462 @ 60^{\circ} \mathrm{F}$ \\
\hline Flashpoint (COC) & $460^{\circ} \mathrm{F}$ \\
\hline Viscosity @ $212^{\circ} \mathrm{F}$ & 13 \\
\hline API Gravity & 26.4 \\
\hline
\end{tabular}

Approximately 1,000 gallons of fuel blended with each additive was used in the engines before testing began. Table 6 lists the fuel and additive amounts that were used in the break-in periods and the manufacturers' recommended ratios.

Table 6. Additives and fuel for break-in periods and testing.

\begin{tabular}{|c|c|c|c|c|c|c|c|}
\hline \multirow[b]{2}{*}{ Date } & \multicolumn{2}{|c|}{ Lucas Fuel Additive } & \multirow{2}{*}{$\begin{array}{l}\text { Recommended } \\
\text { Additive Amount } \\
\text { (quarts) }\end{array}$} & \multirow[b]{2}{*}{ Date } & \multicolumn{2}{|c|}{ DurAlt Fuel Additive } & \multirow{2}{*}{$\begin{array}{c}\text { Recommended } \\
\text { Additive Amount } \\
\text { (oz) }\end{array}$} \\
\hline & $\begin{array}{c}\text { Fuel } \\
\text { (gallons) }\end{array}$ & $\begin{array}{l}\text { Additive } \\
\text { (quarts) }\end{array}$ & & & $\begin{array}{c}\text { Fuel } \\
\text { (gallons) }\end{array}$ & Additive (oz) & \\
\hline 09/03/09 & 300 & 3 & 3.0 & $9 / 12 / 09$ & 546 & 23 & 23.296 \\
\hline 09/04/09 & 510 & 5 & 5.1 & 9/14/09 & 142 & 6.85 & 6.05 \\
\hline 09/04/09 & 213 & 2 & 2.13 & $9 / 15 / 09$ & 342 & 16 & 14.592 \\
\hline 09/05/09 & 296 & 3 & 2.96 & $9 / 16 / 09$ & 312 & 13 & 13.312 \\
\hline \multirow[t]{2}{*}{ Total } & 1319 & 13 & 13.19 & 9/17/09 & 181 & 8.5 & 7.72 \\
\hline & & & & Total & 1523 & 67.35 & 64.97 \\
\hline
\end{tabular}




\section{$5 \quad$ Test Results}

\section{Lock and Dam No. 4}

The results for Lock and Dam No. 4 are given in Tables 7, 8 and 9, and shown in Figures 3, 4, and 5 .

During testing, the return fuel flows could not accurately be measured at loads below 50\% with the alcohol injection system operating. During the $25 \%$ load tests, diesel fuel use was diminished to the point that it was boiling in the return system, and the data were highly inconsistent, with typical candidate fuel-use standard deviations of $15 \%$ of the base fuel consumption reading. Consequently, the results of the $25 \%$ load tests were excluded. The percentage changes in fuel consumption for the load bank tests are listed for both the baseline tests as compared to the additive tests, and for the changes between each of the baseline fuel test results.

Table 7. Lock and Dam No. 4 load-bank test results, 50\% load.

\begin{tabular}{|l|l|l|l|}
\hline \multirow{2}{*}{} & \multicolumn{3}{|c|}{$50 \%$ Load Test } \\
\cline { 2 - 4 } & Baseline 1 & \multicolumn{1}{|c|}{ Candidate } & Baseline 2 \\
\hline AVERAGE (Ib/kWh) & NA & 0.406 & 0.565 \\
\hline STDEV (Ib/kWh) & NA & 0.000 & 0.017 \\
\hline Candidate Difference vs. Baseline (Ib/kWh) & NA & - & -0.159 \\
\hline Candidate \% Difference vs. Baseline & NA & - & $-28.14 \%$ \\
\hline Statistically Significant Difference? & NA & - & YES \\
\hline 95\% Confidence Interval (Ib/kWh) & NA & - & 0.005 \\
\hline
\end{tabular}

Note: Baseline 1 fuel return had bubbles in the return fuel line, invalidating the data.

Table 8. Lock and Dam No. 4 load-bank test results, $75 \%$ load.

\begin{tabular}{|l|l|l|l|}
\hline \multirow{2}{*}{} & \multicolumn{3}{|c|}{ 75\% Load Test } \\
\cline { 2 - 4 } & Baseline 1 & Candidate & Baseline 2 \\
\hline AVERAGE Diesel BSFC (Ib/kWh) & 0.530 & 0.464 & 0.535 \\
\hline STDEV Diesel BSFC (Ib/kWh) & 0.001 & 0.001 & 0.002 \\
\hline Candidate Difference vs Baseline (Ib/kWh) & -0.066 & - & -0.072 \\
\hline Candidate \% Difference vs. Baseline & $-12.44 \%$ & - & $-13.36 \%$ \\
\hline Statistically Significant Difference? & YES & - & YES \\
\hline 95\% Confidence Interval (Ib/kWh) & 0.003 & - & 0.005 \\
\hline
\end{tabular}


Table 9. Lock and Dam No. 4 load-bank test results, $90 \%$ load.

\begin{tabular}{|l|l|l|l|}
\hline \multirow{2}{*}{} & \multicolumn{3}{|c|}{ 90\% Load Test } \\
\cline { 2 - 4 } & Baseline 1 & Candidate & Baseline 2 \\
\hline AVERAGE Diesel BSFC (Ib/kWh) & 0.504 & 0.443 & 0.509 \\
\hline STDEV Diesel BSFC (Ib/kWh) & 0.003 & 0.001 & 0.006 \\
\hline Candidate Difference vs Baseline (Ib/kWh) & -0.060 & - & -0.066 \\
\hline Candidate \% Difference vs. Baseline & $-11.99 \%$ & - & $-12.96 \%$ \\
\hline Statistically Significant Difference? & YES & - & YES \\
\hline 95\% Confidence Interval (Ib/kWh) & 0.005 & - & 0.012 \\
\hline
\end{tabular}

Figure 3. Lock and Dam No. 4 load-bank test results, 50\% load.

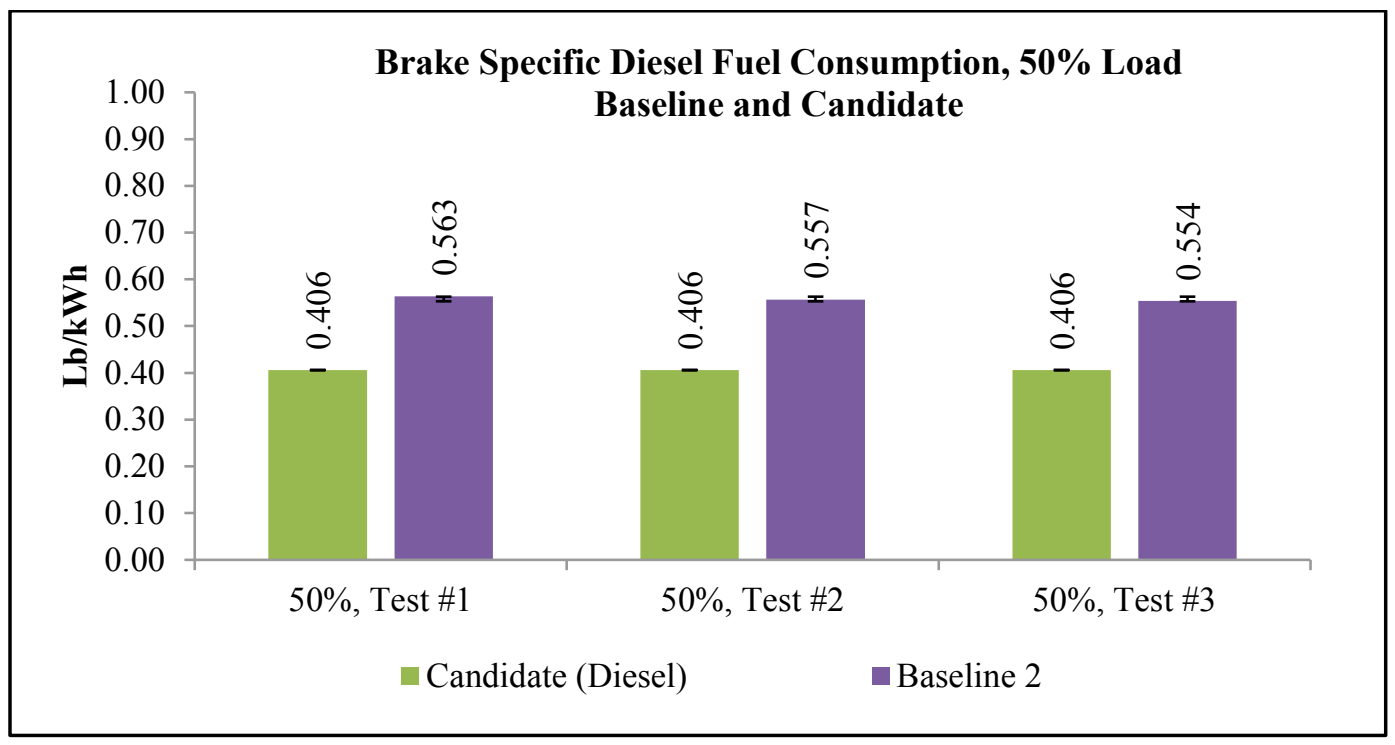

Figure 4. Lock and Dam No. 4 load-bank test results, $75 \%$ load.

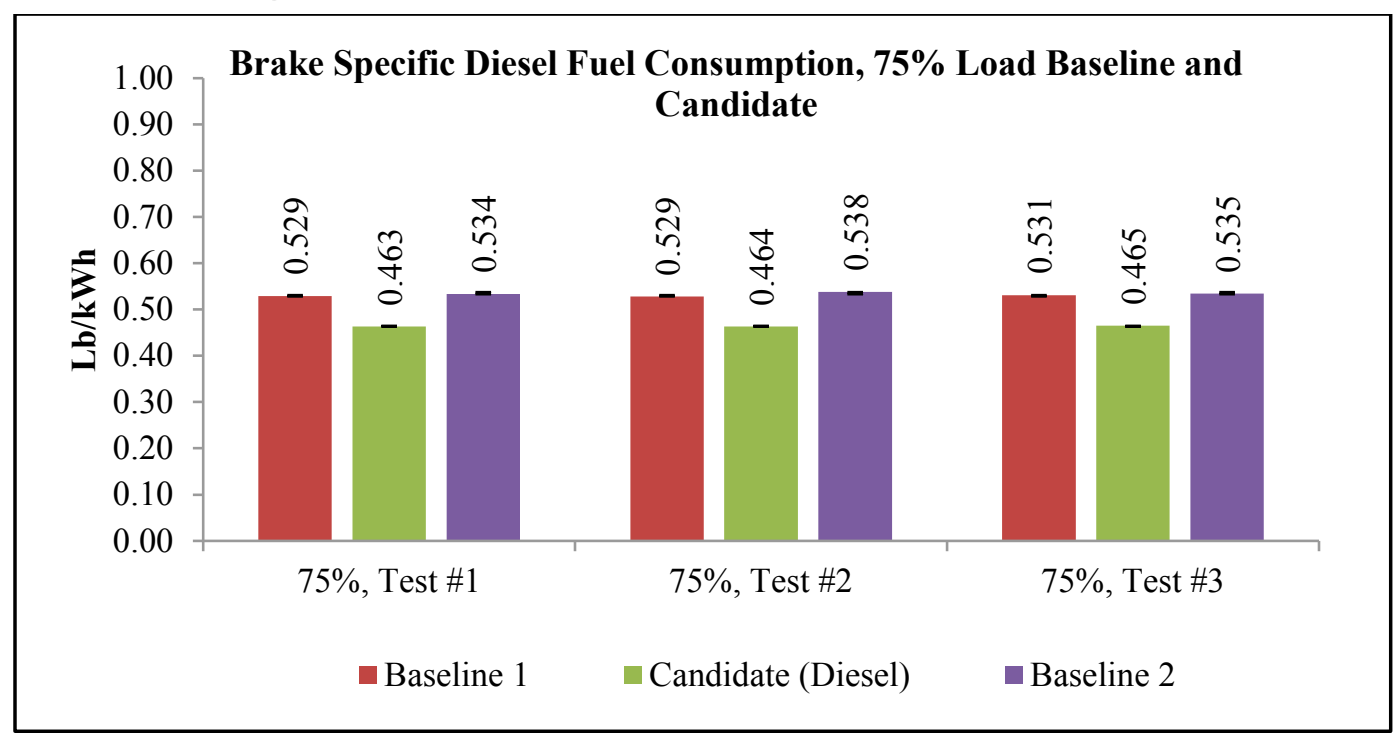


Figure 5. Lock and Dam No. 4 load-bank test results, $90 \%$ load.

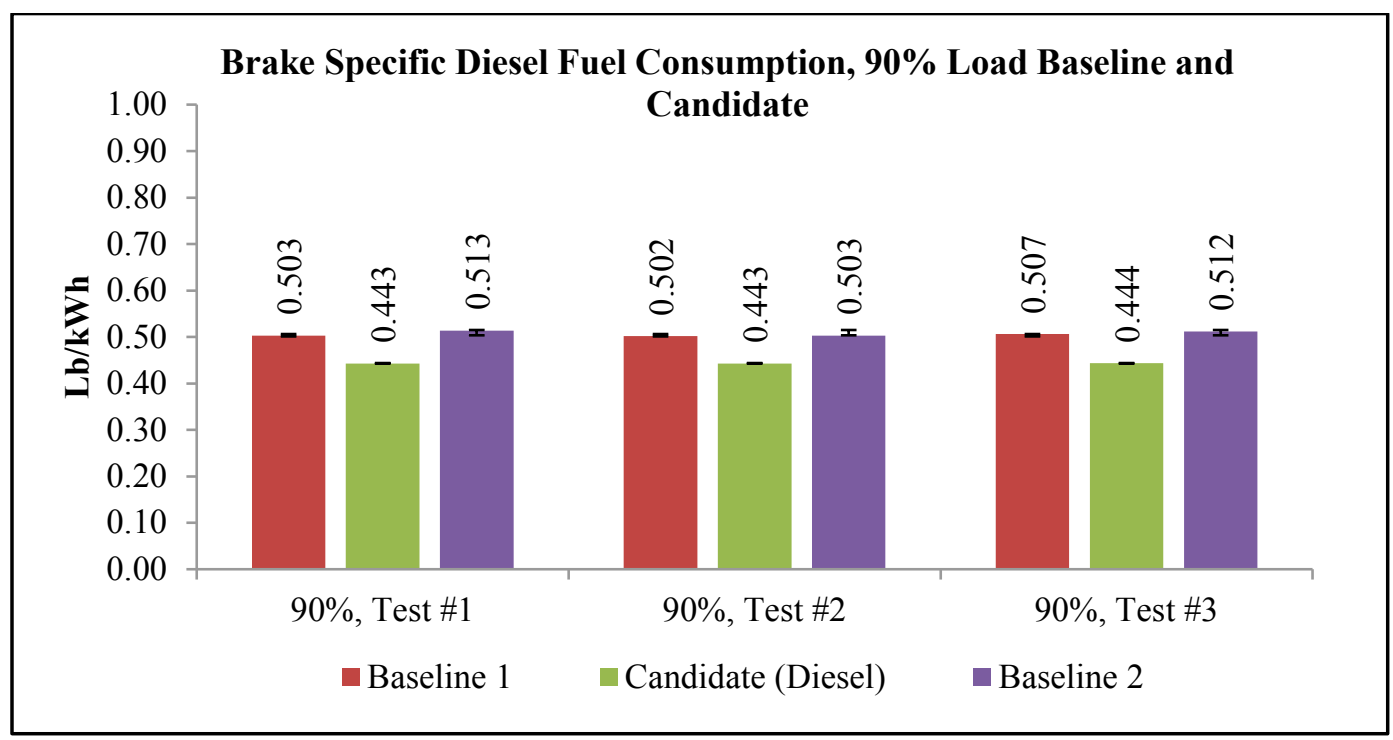

The negative numbers indicate a decrease in fuel usage over the baseline fuel. There are statistically significant differences in diesel fuel consumption when using the candidate alcohol injection system compared to baseline usage at the 50\% load (a reduction of approximately 30\%), and at the $75 \%$ and $90 \%$ generator loads (a reduction of approximately $12 \%$ for both). The higher reduction in diesel fuel usage at the 50\% load is likely because the injection system did not dose alcohol according to any engine load parameters but rather maintained the same injection pressure at all engine loads. Because of this constant injection pressure, alcohol flow was slightly reduced at higher load settings due to increased back pressure in the intake manifold, where the injection took place. As a result of these effects, proportionally more diesel was displaced at $50 \%$ load than at the $75 \%$ and $90 \%$ loads (as reflected by the aforementioned fuel consumption reduction values at different loads).

To determine if using the alcohol injection system had any effect on carbon dioxide $\left(\mathrm{CO}_{2}\right)$ emissions, $\mathrm{CO}_{2}$ emissions per megawatt-hour were estimated. Emissions factors were estimated using the Department of Energy, Specific Energy, Energy Density, and $\mathrm{CO}_{2}$ data for diesel and alcohol. The estimated values are listed in Table 10. Negative numbers indicate a decrease in $\mathrm{CO}_{2}$ production while positive numbers represent an increase. The calculations show decreases in $\mathrm{CO}_{2}$ production at the $50 \%$ and $90 \%$ loads and little or no difference at the $75 \%$ load. 
Table 10. Lock and Dam No. 4 estimated $\mathrm{CO}_{2}$ emission differences.

\begin{tabular}{|c|c|c|c|}
\hline Estimated CO2 Emissions & $50 \%$ Load & $75 \%$ Load & $90 \%$ Load \\
\hline Baseline Diesel Emissions ( $\left(\mathrm{lb}^{-} \mathrm{CO}_{2} / \mathrm{MWh}\right.$ ) & 1822 & 1739 & 1653 \\
\hline Candidate Diesel Emissions ( $\mathrm{Ib}-\mathrm{CO}_{2} / \mathrm{MWh}$ ) & 1325 & 1514 & 1447 \\
\hline Candidate Alcohol Emissions (Ib-CO $/$ /MWh) & 385 & 228 & 186 \\
\hline Candidate Total Emissions (lb- $\left.\mathrm{CO}_{2} / \mathrm{MWh}\right)$ & 1711 & 1742 & 1633 \\
\hline Candidate Difference, \% & $-6.08 \%$ & $0.21 \%$ & $-1.22 \%$ \\
\hline
\end{tabular}

The lock and Dam No. 4 energy output in kWh was compared with the engine's energy input to determine if there was an improvement in engine efficiency when using the alcohol injection system. Figure 6 shows the average BTU input per fuel type and subsequent $\mathrm{kWh}$ output for

Figure 6. Lock and Dam No. 4 BTU input and engine output.

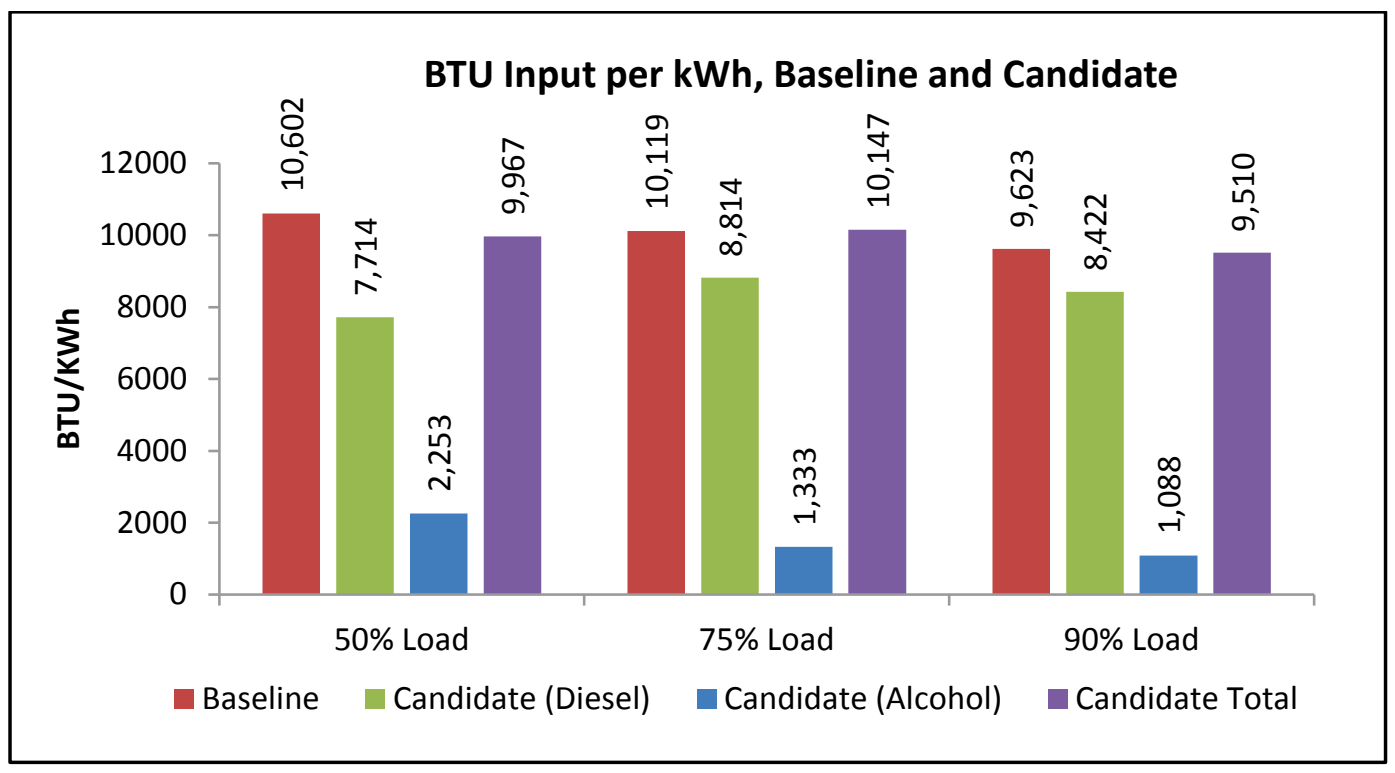

each test load during baseline and candidate testing. In the figure, the first bar represents the BTU content of the fuel used during the baseline conditions. The second and third bar in the graph represent the diesel and alcohol fuel BTU content used during the candidate conditions, and the final bar represents the total BTU of fuel used during the candidate conditions. The calculations were based on BTU contents found on the GREET Transportation Fuel Cycle Analyses Model (Argone National Laboratory 2008). The BTU content of a gallon of ethanol and diesel used to calculate the results is 76,300 and 128,450 , respectively. The engine is more efficient with the candidate system at the $50 \%$ and $90 \%$ loads by $5.98 \%$ and $1.17 \%$, respectively, and less efficient at the $75 \%$ load by $0.27 \%$. 


\section{Taggatz}

The test loads for the Taggatz are listed for port engine-generator set in Table 11 and for the starboard engine-generator set in Table 12. The percentages are the percent differences from the target test design loads. For the port engine, the data for the $25 \%$ load were eliminated from the analysis because of the difference between baseline and candidate engine loading. The discrepancy was the result of a miscommunication between the test personnel and the load-bank operator.

Table 11. Taggatz port test loads.

\begin{tabular}{|c|c|c|c|c|c|}
\hline Test Load & $\begin{array}{c}\text { Port Baseline } \\
\text { Load Average }\end{array}$ & $\begin{array}{c}\text { Baseline Load \% } \\
\text { from Target }\end{array}$ & $\begin{array}{c}\text { Target } \\
\text { Load }\end{array}$ & $\begin{array}{c}\text { Port Candidate } \\
\text { Load Average }\end{array}$ & $\begin{array}{c}\text { Candidate Load \% } \\
\text { from Target }\end{array}$ \\
\hline $\begin{array}{c}\% \text { of Max } \\
(330 \mathrm{~kW})\end{array}$ & $\mathrm{kW}$ & $\%$ & $\mathrm{~kW}$ & $\mathrm{~kW}$ & $\%$ \\
\hline 25 & 68.37 & $-17.12 \%$ & 82.5 & 83.90 & $1.69 \%$ \\
\hline 50 & 161.16 & $-2.33 \%$ & 165 & 165.55 & $0.33 \%$ \\
\hline 75 & 245.02 & $-1.00 \%$ & 247.5 & 246.50 & $-0.40 \%$ \\
\hline 85 & 270.89 & $-3.43 \%$ & 280.5 & 274.81 & $-2.03 \%$ \\
\hline
\end{tabular}

Table 12. Taggatz starboard test loads.

\begin{tabular}{|c|c|c|c|c|c|}
\hline Test Load & $\begin{array}{c}\text { Starboard } \\
\text { Baseline Load } \\
\text { Average }\end{array}$ & $\begin{array}{c}\text { Starboard Baseline } \\
\text { Load \% from Target }\end{array}$ & $\begin{array}{c}\text { Target } \\
\text { Load }\end{array}$ & $\begin{array}{c}\text { Starboard } \\
\text { Candidate Load \% } \\
\text { from Target }\end{array}$ & $\begin{array}{c}\text { Starboard Candidate } \\
\text { Load Average }\end{array}$ \\
\hline $\begin{array}{c}\% \text { of Max } \\
(330 \mathrm{~kW})\end{array}$ & $\mathrm{kW}$ & $\%$ & $\mathrm{~kW}$ & $\%$ & $\mathrm{~kW}$ \\
\hline 25 & 81.24 & $-1.53 \%$ & 82.5 & $1.98 \%$ & 84.14 \\
\hline 50 & 164.86 & $-0.08 \%$ & 165 & $1.13 \%$ & 166.86 \\
\hline 75 & 244.75 & $-1.11 \%$ & 247.5 & $-0.01 \%$ & 247.48 \\
\hline 85 & 280.29 & $-0.07 \%$ & 280.5 & $1.34 \%$ & 284.27 \\
\hline
\end{tabular}

The port test results are listed in Tables 13, 14, and 15 and shown in Figures 7, 8, and 9, and the starboard test results are shown in Tables 16, 17, 18, and 19 and Figures 10, 11, 12, and 13. Positive numbers indicate an increase in fuel usage over baseline fuel usage, and negative numbers indicate a decrease in fuel usage over baseline fuel usage. 
Table 13. Taggatz port test results, $50 \%$ load.

\begin{tabular}{|l|c|c|}
\hline \multirow{2}{*}{} & \multicolumn{2}{|c|}{ 50\% Load Test } \\
\cline { 2 - 3 } & Baseline 1 & Candidate \\
\hline AVERAGE (Ib/kWh) & 0.532 & 0.512 \\
\hline STDEV (Ib/kWh) & 0.002 & 0.001 \\
\hline Candidate Difference vs. Baseline (Ib/kWh) & 0.020 & - \\
\hline Candidate \% Difference vs. Baseline & $-3.73 \%$ & - \\
\hline Statistically Significant Difference & YES & - \\
\hline 95\% Confidence Interval (Ib/kWh) & 0.003 & - \\
\hline
\end{tabular}

Table 14. Taggatz port test results, $75 \%$ load.

\begin{tabular}{|l|c|c|}
\hline \multirow{2}{*}{} & \multicolumn{2}{|c|}{$75 \%$ Load Test } \\
\cline { 2 - 3 } & Baseline 1 & Candidate \\
\hline AVERAGE Diesel BSFC (Ib/kWh) & 0.502 & 0.495 \\
\hline STDEV Diesel BSFC (Ib/kWh) & 0.001 & 0.000 \\
\hline Candidate Difference vs Baseline (Ib/kWh) & 0.006 & - \\
\hline Candidate \% Difference vs. Baseline & $-1.28 \%$ & - \\
\hline Statistically Significant Difference? & YES & - \\
\hline 95\% Confidence Interval (Ib/kWh) & 0.007 & - \\
\hline
\end{tabular}

Table 15. Taggatz port test results, $85 \%$ load.

\begin{tabular}{|l|l|l|}
\hline \multirow{2}{*}{} & \multicolumn{2}{|c|}{ 75\% Load Test } \\
\cline { 2 - 3 } & \multicolumn{1}{|c|}{ Baseline 1 } & Candidate \\
\hline AVERAGE Diesel BSFC (Ib/kWh) & 0.506 & 0.458 \\
\hline STDEV Diesel BSFC (Ib/kWh) & 0.010 & 0.003 \\
\hline Candidate Difference vs Baseline (Ib/kWh) & 0.048 & - \\
\hline Candidate \% Difference vs. Baseline & $-9.51 \%$ & - \\
\hline Statistically Significant Difference? & YES & - \\
\hline 95\% Confidence Interval (Ib/kWh) & 0.021 & - \\
\hline
\end{tabular}


Figure 7. Taggatz port generator baseline and candidate BSFC, 50\% load.

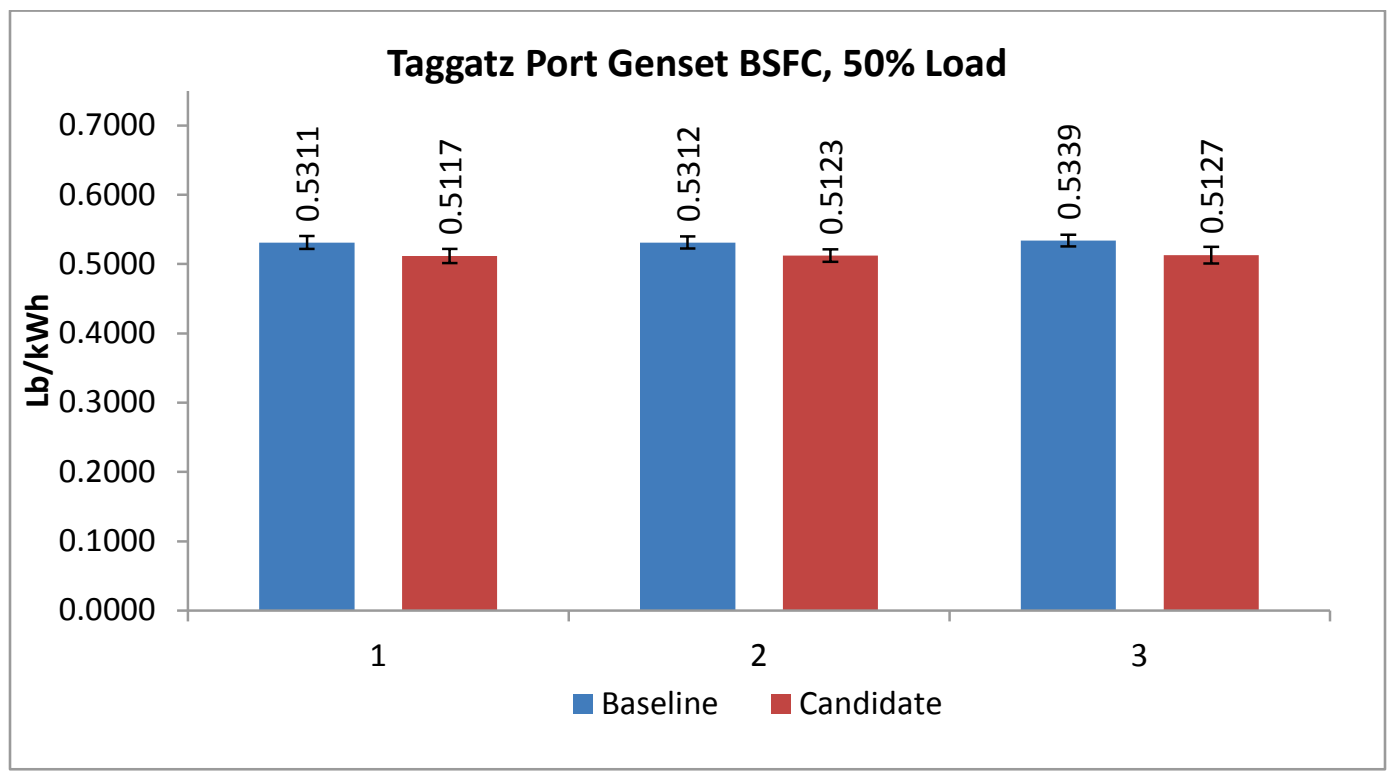

Figure 8. Taggatz port generator baseline and candidate BSFC, $75 \%$ load.

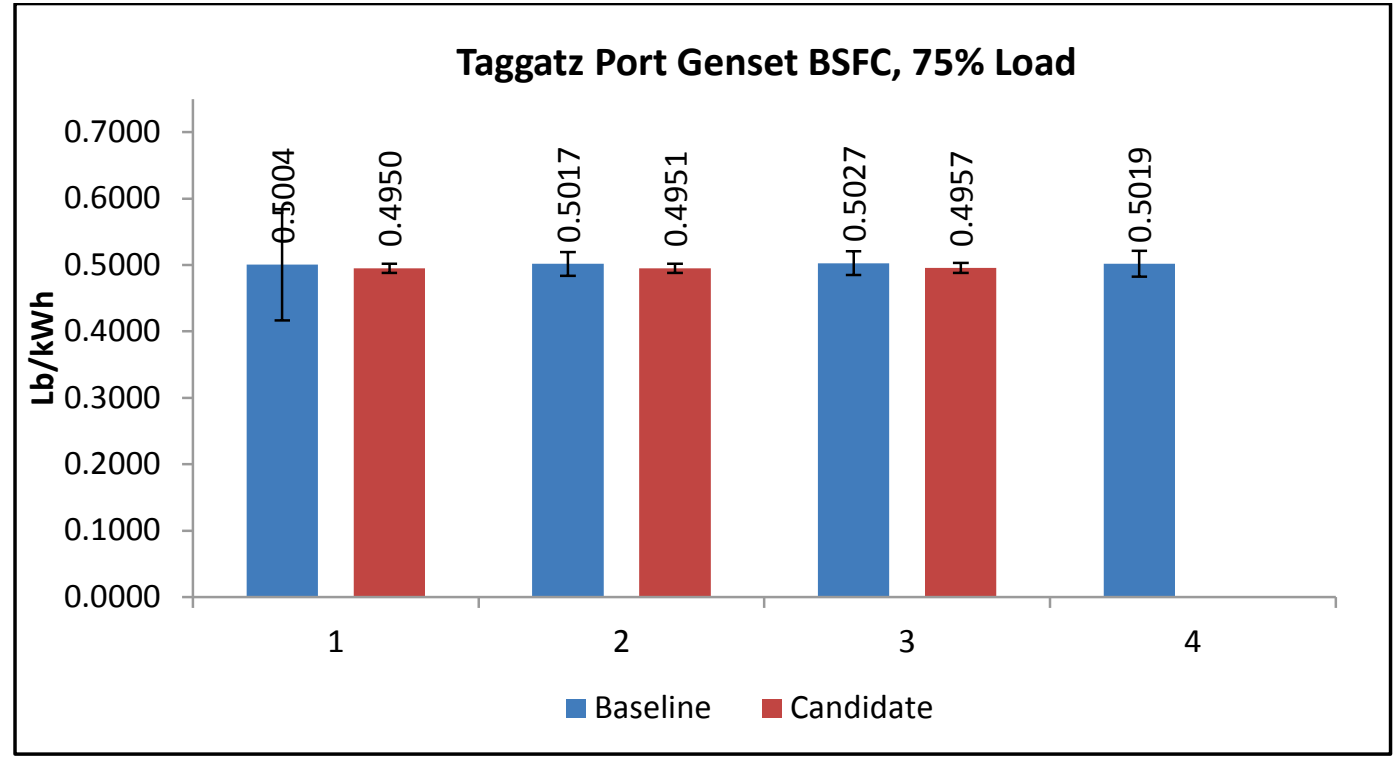


Figure 9. Taggatz port generator baseline and candidate BSFC, $85 \%$ load.

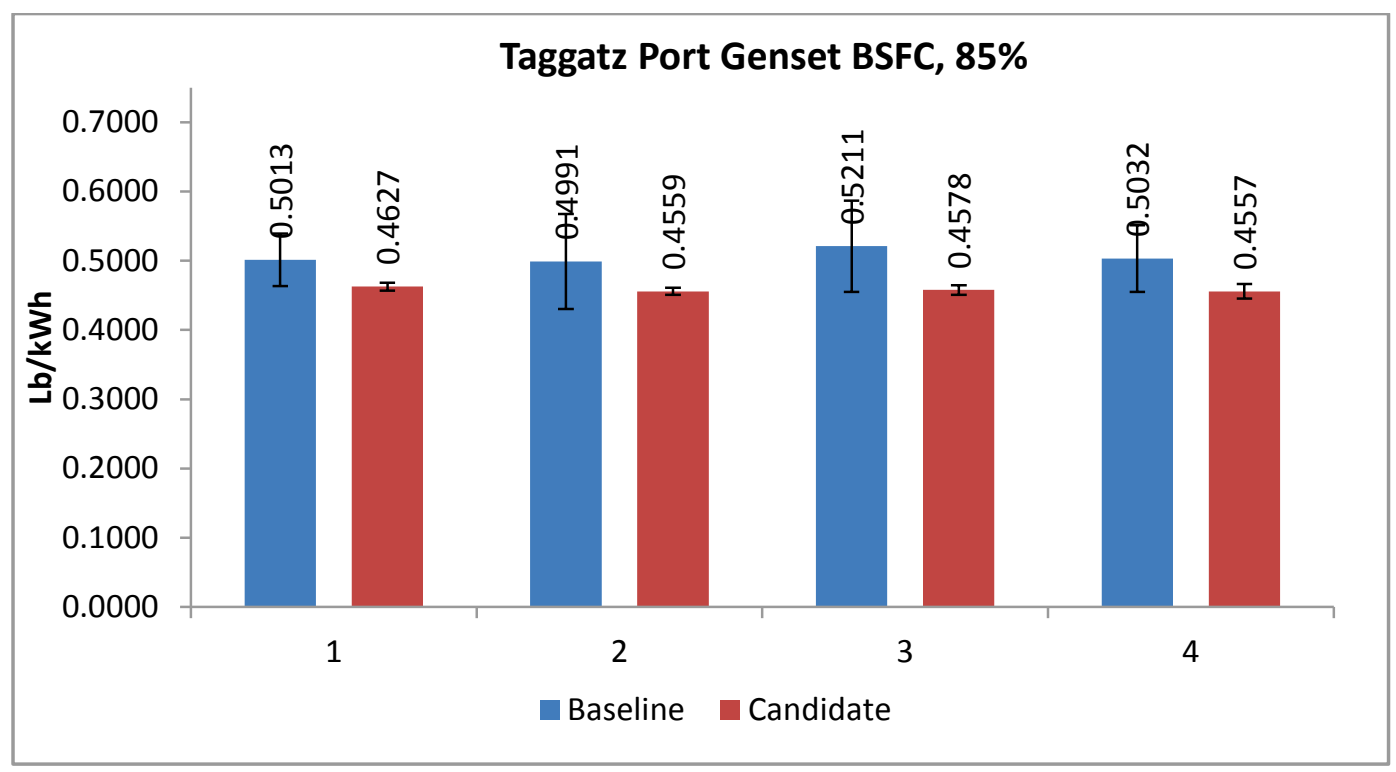

Table 16. Taggatz starboard test results, $25 \%$ load.

\begin{tabular}{|l|c|c|}
\hline \multirow{2}{*}{} & \multicolumn{2}{|c|}{ 25\% Load Test } \\
\cline { 2 - 3 } & Baseline 1 & Candidate \\
\hline AVERAGE (Ib/kWh) & 0.615 & 0.636 \\
\hline STDEV (Ib/kWh) & 0.006 & 0.006 \\
\hline Candidate Difference vs Baseline (Ib/kWh) & 0.020 & - \\
\hline Statistically Significant Difference? & $3.32 \%$ & - \\
\hline 95\% Confidence Interval (lb/kWh) & YES & - \\
\hline
\end{tabular}

Table 17. Taggatzstarboard test results, 50\% load.

\begin{tabular}{|l|c|c|}
\hline \multirow{2}{*}{} & \multicolumn{2}{|c|}{$50 \%$ Load Test } \\
\cline { 2 - 3 } & Baseline 1 & Candidate \\
\hline AVERAGE (Ib/kWh) & 0.515 & 0.520 \\
\hline STDEV (Ib/kWh) & 0.003 & 0.003 \\
\hline Candidate Difference vs Baseline (Ib/kWh) & 0.007 & - \\
\hline Candidate \% Difference vs. Baseline & $1.02 \%$ & - \\
\hline Statistically Significant Difference? & No & - \\
\hline 95\% Confidence Interval (Ib/kWh) & 0.007 & - \\
\hline
\end{tabular}


Table 18. Taggatz starboard test results, $75 \%$ load.

\begin{tabular}{|l|c|c|}
\hline \multirow{2}{*}{} & \multicolumn{2}{|c|}{$75 \%$ Load Test } \\
\cline { 2 - 3 } & Baseline 1 & Candidate \\
\hline AVERAGE Diesel BSFC (Ib/kWh) & 0.494 & 0.501 \\
\hline STDEV Diesel BSFC (Ib/kWh) & 0.000 & 0.007 \\
\hline Candidate Difference vs Baseline (Ib/kWh) & 0.007 & - \\
\hline Candidate \% Difference vs. Baseline & $1.33 \%$ & - \\
\hline Statistically Significant Difference? & No & - \\
\hline 95\% Confidence Interval (lb/kWh) & 0.015 & - \\
\hline
\end{tabular}

Table 19. Taggatz starboard test results, $85 \%$ load.

\begin{tabular}{|l|c|c|}
\hline \multirow{2}{*}{} & \multicolumn{2}{|c|}{$\mathbf{8 5 \%}$ Load Test } \\
\cline { 2 - 3 } & Baseline 1 & Candidate \\
\hline AVERAGE Diesel BSFC (Ib/kWh) & 0.489 & 0.496 \\
\hline STDEV Diesel BSFC (Ib/kWh) & 0.001 & 0.002 \\
\hline Candidate Difference vs Baseline (Ib/kWh) & 0.007 & - \\
\hline Candidate \% Difference vs. Baseline & $1.51 \%$ & - \\
\hline Statistically Significant Difference? & YES & - \\
\hline 95\% Confidence Interval (lb/kWh) & 0.004 & - \\
\hline
\end{tabular}

Figure 10. Taggatz starboard generator and candidate baseline BSFC, 25\% load.

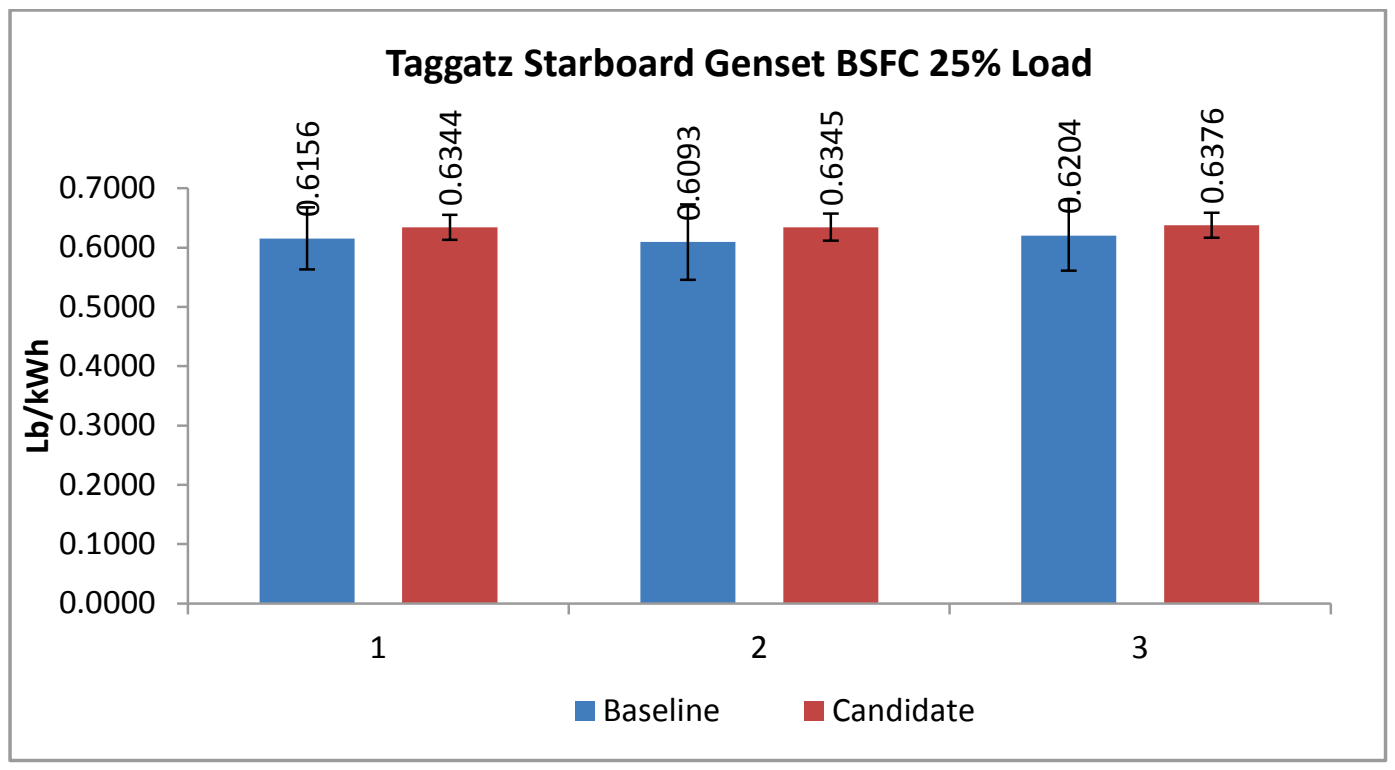


Figure 11. Taggatz starboard generator baseline BSFC, $50 \%$ load.

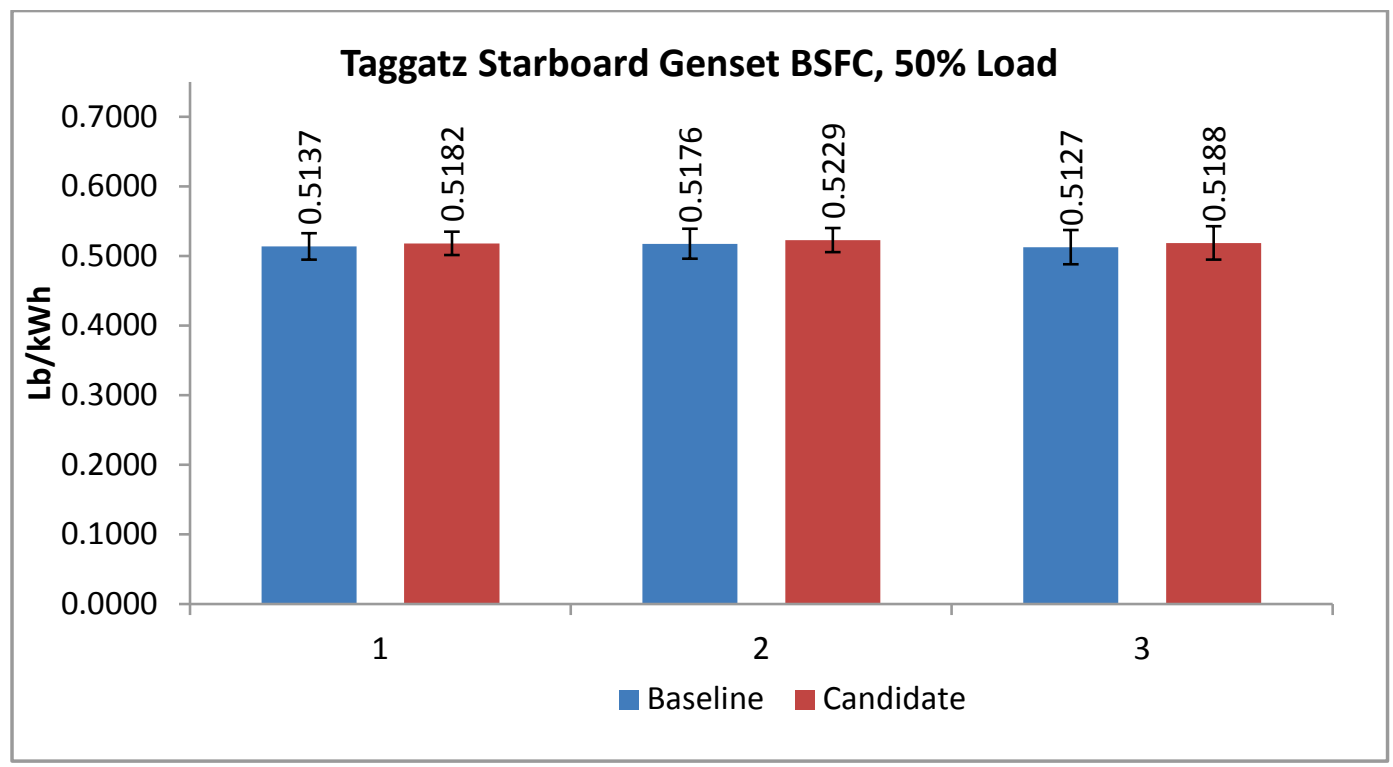

Figure 12. Taggatz starboard generator baseline BSFC, $75 \%$ load.

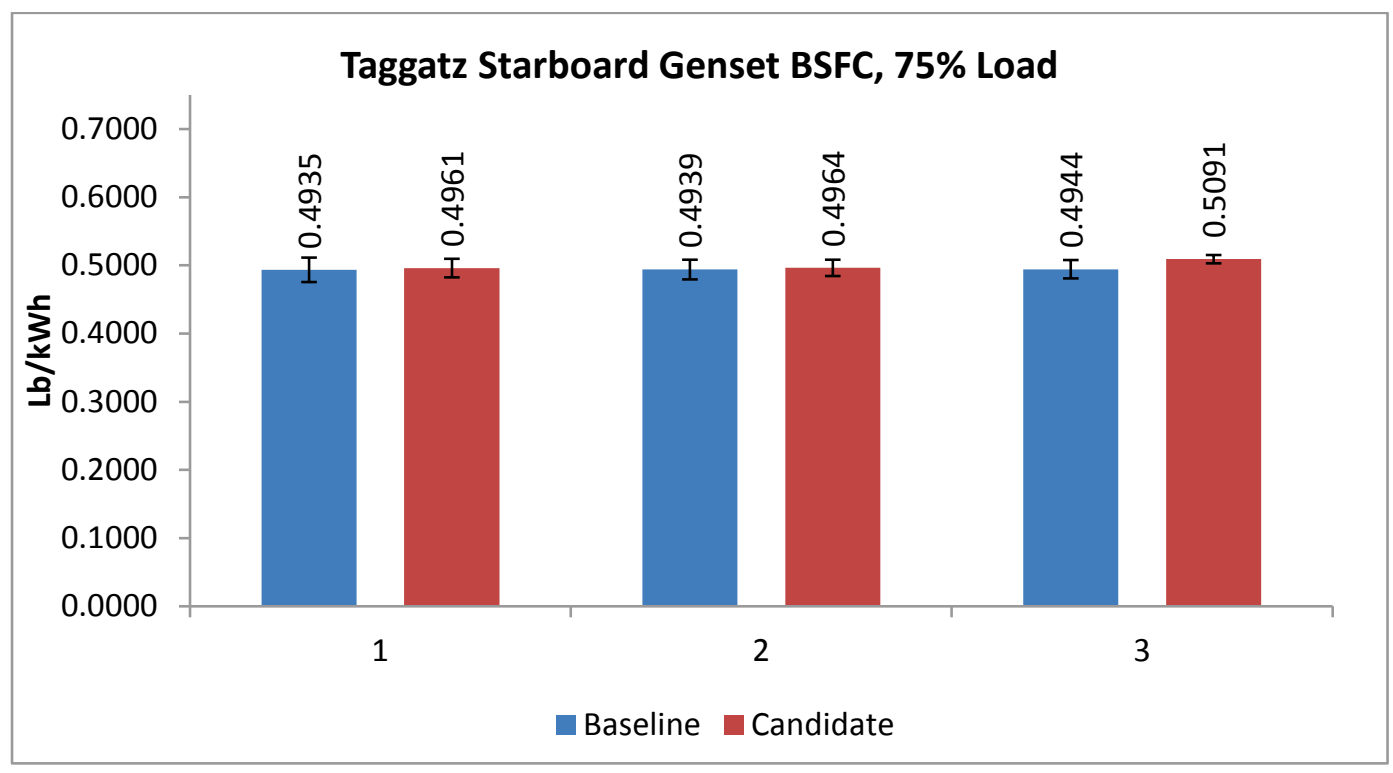


Figure 13. Taggatz starboard generator baseline BSFC, $85 \%$ load.

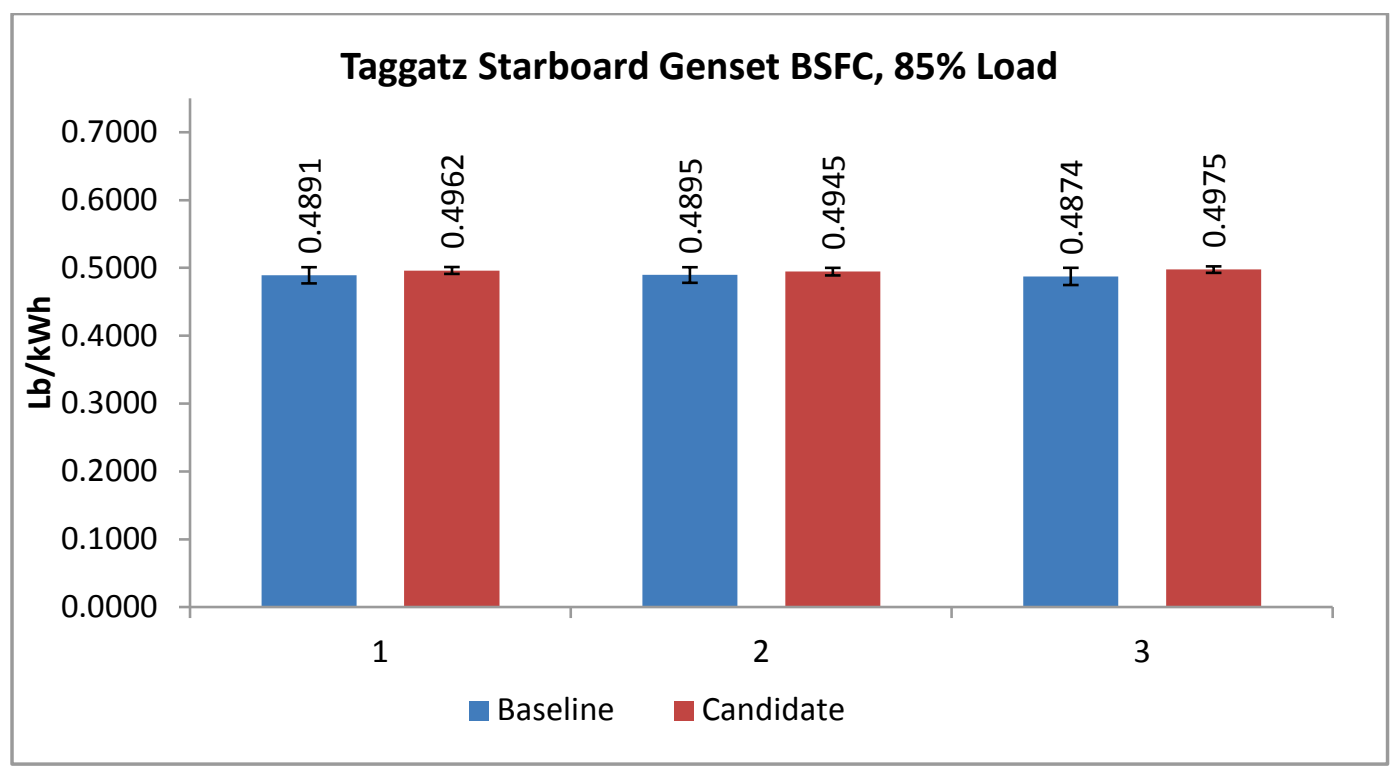

All of the port-side results were shown to be statistically significant. However, for the starboard side, only the $25 \%$ and $85 \%$ load tests, which showed a slight increase in fuel consumption during the additive testing, are statistically significant. The candidate additive shows fuel use decreases of $3.73 \%, 1.28 \%$, and $9.51 \%$ for port engine loads of $50 \%, 75 \%$, and $85 \%$, and increases of $3.32 \%, 1.02 \%, 1.13 \%$, and $1.51 \%$ for starboard engine loads of $25 \%, 50 \%, 75 \%$, and $85 \%$.

The port engine's governor actuator required replacement after the baseline testing had been performed and also required slight adjustments during the degreening period. The actuator helps the engine maintain a constant speed of $1800 \mathrm{rpm}$, thereby allowing the generator to produce a steady amount of energy. After the degreening period had begun, engine speed variation was noticed, and the necessary parts were replaced.

The starboard engine's fuel and load data were consistent, and data collection and analyses were conducted without problems. Since the starboard engine showed a statistically significant increase in fuel consumption during candidate testing at the $85 \%$ load, the $9.51 \%$ decrease in fuel consumption at the $85 \%$ load for the port engine is discounted. Overall, the conclusions are that the starboard engine results are the reliable ones and that the additive did not reduce fuel consumption. The problem with the port engine results may be the result of an improperly tuned governor actuator. 


\section{Pathfinder}

The bollard-push test results for the Pathfinder are presented in Figure 14 and Table 20. As illustrated in Figure 14, at each load condition, little change is observed in the fuel consumption from baseline to candidate. In Table 20, the percent change in fuel consumption for the bollard push tests are listed for the baselines as compared to the additive and the changes between each of the baseline fuel test results. Comparisons are made between the fuel consumption during baseline 1 (BL1) or baseline 2 (BL2) and candidate 1 ( $\mathrm{C} 1$ - Lucas) and separately between baseline 2 (BL2) or baseline 3 (BL3) and candidate 2 (C2 - DurAlt). Positive numbers indicate a slight increase in fuel usage over the baseline fuel usage. The negative numbers indicate a decrease in fuel usage compared to that of the baseline fuel. No statistics could be performed on these results because these tests were performed as a single test for a long duration of time.

Figure 14. Pathfinder bollard push test results at different loads.

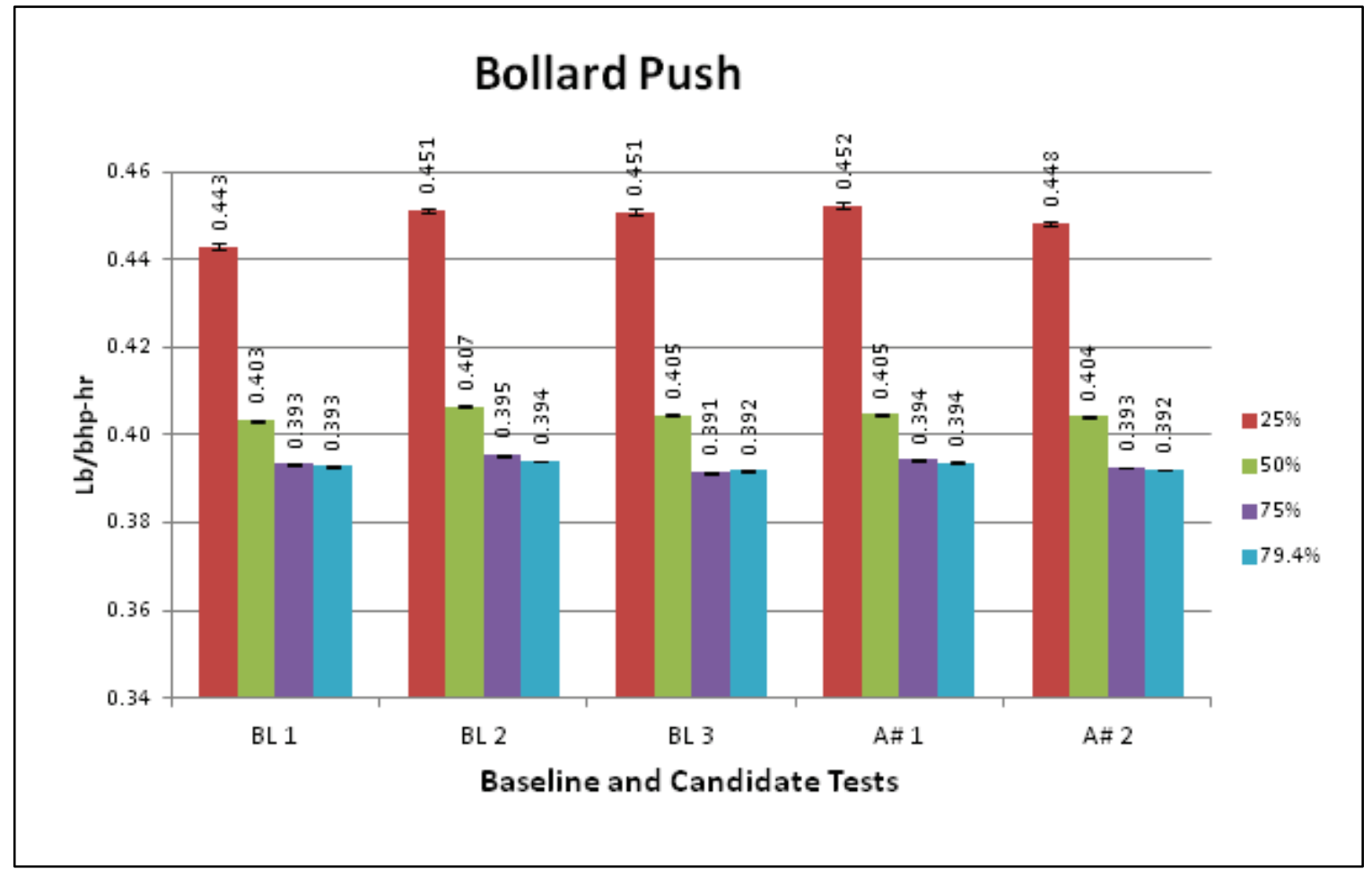


Table 20. Pathfinder bollard-push baseline and candidate fuel consumption changes.

\begin{tabular}{|c|c|c|c|c|c|c|}
\hline $\begin{array}{c}\text { Load } \\
\%\end{array}$ & $\begin{array}{c}\text { Percent } \\
\text { Change } \\
\text { BL1 to C1 }\end{array}$ & $\begin{array}{c}\text { Percent } \\
\text { Change } \\
\text { BL2 to C1 }\end{array}$ & $\begin{array}{c}\text { Percent } \\
\text { Change } \\
\text { BL1 to BL2 }\end{array}$ & $\begin{array}{c}\text { Percent } \\
\text { Change } \\
\text { BL2 to C2 }\end{array}$ & $\begin{array}{c}\text { Percent } \\
\text { Change } \\
\text { BL2 to BL3 }\end{array}$ & $\begin{array}{c}\text { Percent } \\
\text { Change } \\
\text { BL3 to C2 }\end{array}$ \\
\hline 25 & 2.0896 & 0.2565 & 1.8378 & -0.6680 & -0.0699 & -0.5977 \\
\hline 50 & 0.3325 & -0.4675 & 0.7963 & -0.5741 & -0.4950 & -0.0787 \\
\hline 75 & 0.2268 & -0.2953 & 0.5206 & -0.7408 & -1.0103 & 0.2668 \\
\hline 100 & 0.2309 & -0.0869 & 0.3176 & -0.5050 & -0.5651 & 0.0598 \\
\hline
\end{tabular}

The duty-cycle test results for the Pathfinder are presented in Table 21 and Figure 15. As presented in Table 21 and Figure 15, the impacts of the additives on fuel consumption appear to be minimal for the operating regimes under which the tests were completed. Statistical significance was calculated using a two-tailed t-test evaluation. Only one difference was found to be statistically different, the BL1 to C1 difference of -1.8924 at $25 \%$ load.

It should be noted that the in-use tests were completed while traveling downstream and then while traveling upstream. Because of the impacts of the current on engine power delivered to the shaft, there were slight differences between the fuel consumption when operating in each direction. The data presented in Table 21 and Figure 15 aggregate all test runs (two each of up and downstream) into a single mean fuel consumption rate and associated standard deviation. However, as a worst case, the statistical significance of any changes between additive-dosed and baseline fuels for upstream-only and downstream-only data was evaluated. In each case, the slight decrease of the standard deviation due to the elimination of the downstream data (and vice versa) did not impact the statistical significance of any observed changes.

Table 21. Pathfinder duty-cycle baseline and candidate fuel consumption changes.

\begin{tabular}{|c|c|c|c|c|c|c|}
\hline $\begin{array}{c}\text { Load } \\
\%\end{array}$ & $\begin{array}{c}\text { Percent } \\
\text { Change } \\
\text { BL1 to C1 }\end{array}$ & $\begin{array}{c}\text { Percent } \\
\text { Change } \\
\text { BL2 to C1 }\end{array}$ & $\begin{array}{c}\text { Percent } \\
\text { Change } \\
\text { BL1 to BL2 }\end{array}$ & $\begin{array}{c}\text { Percent } \\
\text { Change } \\
\text { BL2 to C2 }\end{array}$ & $\begin{array}{c}\text { Percent } \\
\text { Change } \\
\text { BL2 to BL3 }\end{array}$ & $\begin{array}{c}\text { Percent } \\
\text { Change } \\
\text { BL3 to C2 }\end{array}$ \\
\hline 25 & -1.8924 & -0.8321 & -1.0515 & -0.2160 & -1.0053 & 0.3126 \\
\hline 50 & 0.0076 & -0.2339 & 0.2409 & -0.1952 & -1.2169 & 0.6669 \\
\hline 75 & 0.2742 & -0.2659 & 1.7230 & -0.2746 & -1.1072 & 0.4175 \\
\hline 100 & 0.2032 & 0.0005 & 0.2027 & 0.0721 & -0.4695 & 0.3594 \\
\hline
\end{tabular}


Figure 15. Duty-cycle test results at different loads.

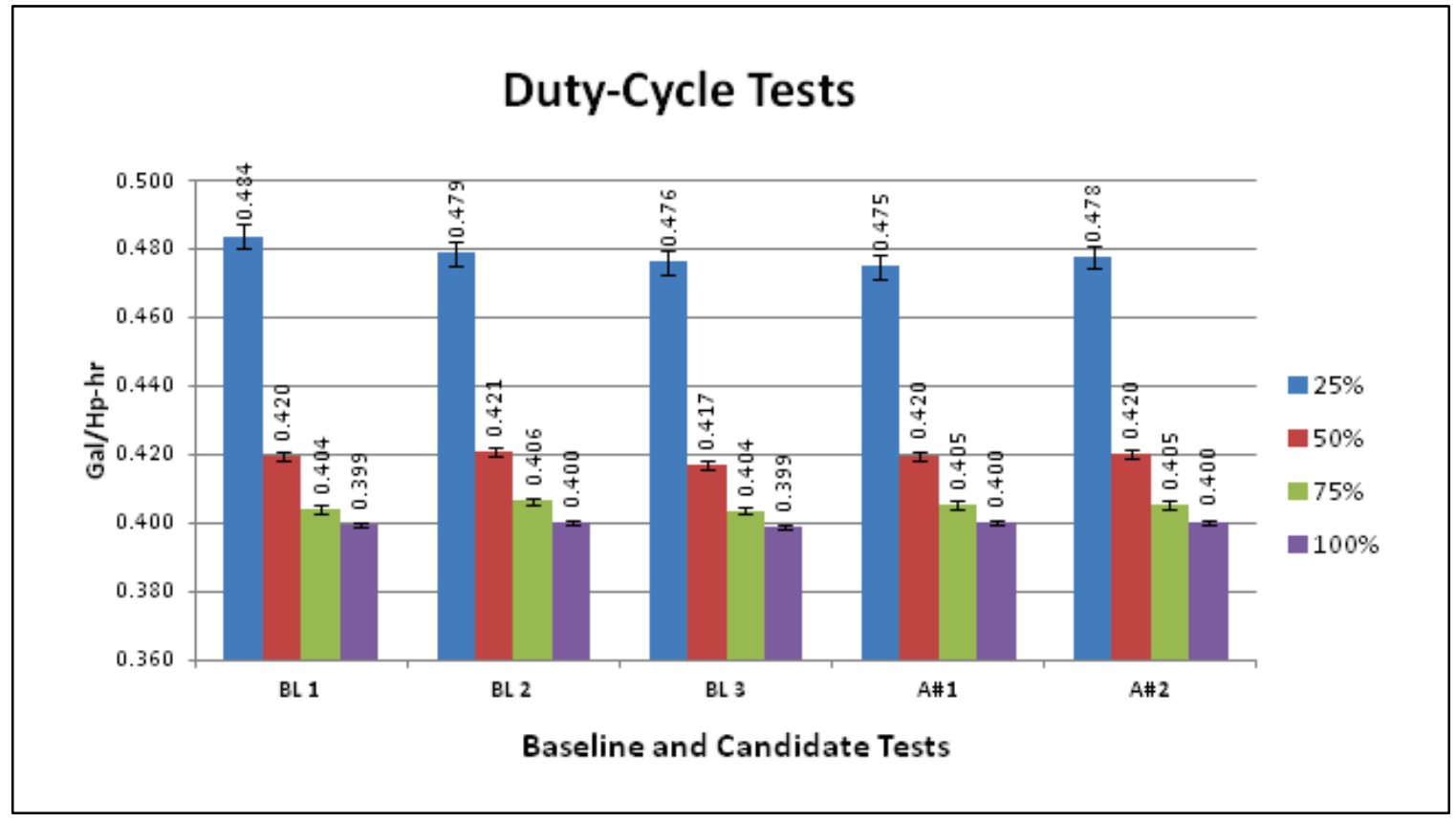




\section{Summary and Conclusions}

Four fuel additives were tested to evaluate their potential for reducing diesel fuel consumption and cost:

- An ethanol injection system

- Envirofuels Diesel Fuel Catalyst

- DurAlt Fuel Conditioner

- Lucas Fuel Treatment.

Fuel usage was measured while using the additives with diesel fuel (candidate tests) and compared to fuel usage under the same conditions while using only standard diesel fuel (baseline tests). The tests were conducted on diesel generator sets at the USACE Lock and Dam 4 Service Base (ethanol injection) in Alma, WI, the quarters boat Taggatz (Envirofuels Diesel Fuel Catalyst) located near Wabasha, MN, and the towboat Pathfinder (DurAlt Fuel Conditioner and Lucas Fuel Treatment) located in Saint Louis, MO. The evaluations were conducted in the field under actual, in-use operating conditions. The results are applicable to the host engines and operating conditions, but similar results can be expected for similar engine families, year of manufacture, and operating regimes. While the Envirofuels, DurAlt, and Lucas additives showed limited fuel reduction in select operation conditions, only the ethanol injection system consistently showed potential to reduce diesel fuel consumption.

During the candidate test runs, diesel fuel consumption using the ethanol injection system was reduced by an average of $30 \%$ at the $50 \%$ loads, and $12 \%$ at the $75 \%$ and $90 \%$ loads. The lower reduction in diesel fuel usage at the higher load levels is likely due to the injection system's static flow rate and sensitivity to turbocharger boost pressures. Instead of maintaining the same alcohol mass flow at all engine loads, this caused a decrease in the alcohol dosing at the higher power levels. As a result, proportionally more diesel was displaced at 50\% than at the $75 \%$ and $90 \%$ loads. The engine was found to be more efficient with the candidate system at the 50\% and $90 \%$ loads by $5.98 \%$ and $1.17 \%$, respectively, and less efficient at the $75 \%$ load by $0.27 \%$. 
While using the alcohol injection system, it was found that $\mathrm{CO}_{2}$ emissions were reduced by $6.08 \%$ for the $50 \%$ load, $0.21 \%$ at the $75 \%$ load and $1.22 \%$ at the $90 \%$ load. It is possible that if the alcohol injection amount had remained constant throughout the different loading conditions or had a more variable flow rate that scales proportionally with diesel use, the higher load results would have more resembled the data collected at the $50 \%$ load condition. 


\section{References}

American Bureau of Shipping. 2006. Rules for building and classing steel vessels under 90 meters (295 feet) in length, 2006, part 5: Specialized vessels and services. Chapter 8, Vessels Intended for Towing, Appendix 2, Guidelines for Bollard Pull Test Procedure (2001). Houston, TX: American Bureau of Shipping.

Argonne National Laboratory. 2008. GREET transportation fuel cycle analyses model. Argonne, IL: Argonne National Laboratory.

Office of the Press Secretary, 2009. Federal leadership in environmental, energy, and economic performance. Executive Order 13514. Washington, DC: White House.

Richards, Haggis. 2007. Generic in-use test protocol for nonroad equipment. Agreement \#8958. Albany, NY: Southern Research Institute and New York State Energy Research and Development Authority.

SAE International. 1986. Surface vehicle recommended practice, joint TMC/SAE fuel consumption test procedure-Type II, SAE J1321. Warrendale, PA: SAE International.

Southern Research Institute, Advanced Energy and Transportation Technologies Department. 2009. Diesel fuel additives as applied to U.S. Army Corps of Engineers motor vessel Pathfinder. 27 October 2009. Durham, NC: Southern Research Institute.

Southern Research Institute, Advanced Energy and Transportation Technologies Department. 2010. Diesel fuel additives as applied to U.S. Army Corps of Engineers lock generator and quarters boat Taggatz. 18 November 2010. Durham, NC: Southern Research Institute. 


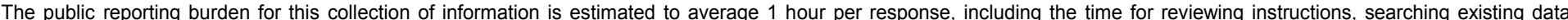

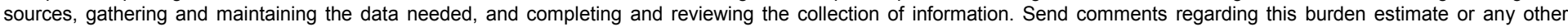

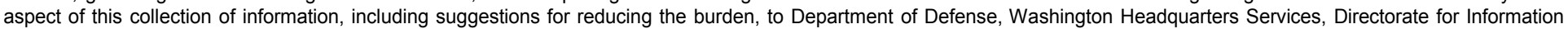

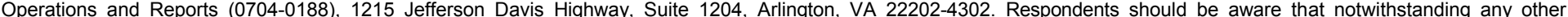
provision of law, no person shall be subject to any penalty for failing to comply with a collection of information if it does not display a currently valid OMB control number. PLEASE DO NOT RETURN YOUR FORM TO THE ABOVE ADDRESS.

\begin{tabular}{l|l}
$\begin{array}{l}\text { 1. REPORT DATE } \\
\text { July } 2016\end{array}$ & $\begin{array}{l}\text { 2. REPORT TYPE } \\
\text { Technical Report }\end{array}$ \\
\hline $\begin{array}{l}\text { 4. TITLE AND SUBTITLE } \\
\text { Evaluation Tests of Select Fuel Additives for Potential Use in U.S. Army Corps of } \\
\text { Engineers Diesel Engines }\end{array}$
\end{tabular}

Engineers Diesel Engines
3. DATES COVERED (From - To)

Aug 2009 - Jan 2015

5a. CONTRACT NUMBER

5b. GRANT NUMBER

5c. PROGRAM ELEMENT NUMBER

5d. PROJECT NUMBER

5e. TASK NUMBER

5f. WORK UNIT NUMBER

456009

8. PERFORMING ORGANIZATION
REPORT NUMBER

ERDC/CHL TR-16-10

Engineer Research and Development Center

3909 Halls Ferry Road

Vicksburg MS, 39180

9. SPONSORING/MONITORING AGENCY NAME(S) AND ADDRESS(ES)

U.S. Army Corps of Engineers

Washington, DC 20314-1000

\section{SPONSO}

11. SPONSOR/MONITOR'SREPORT NUMBER(S)

\section{DISTRIBUTION/AVAILABILITY STATEMENT}

Approved for public release; distribution is unlimited.

\section{SUPPLEMENTARY NOTES}

\section{ABSTRACT}

Under the Dredging Operations and Environmental Research (DOER) program, diesel fuel additives were tested to evaluate their potential for reducing diesel fuel consumption and cost. Fuel usage was measured while using the additives with diesel fuel (candidate tests) and compared to fuel usage under the same conditions while using only standard diesel fuel (baseline tests). The tests were conducted on diesel generator sets at the Corps' Lock and Dam 4 Service Base (ethanol injection) in Alma, WI, the quarters boat Taggatz (Envirofuels Diesel Fuel Catalyst) located near Wabasha, MN, and the towboat Pathfinder (DurAlt Fuel Conditioner and Lucas Fuel Treatment) located in Saint Louis, Mo. The evaluations were conducted in the field under actual, in-use operating conditions. The results are applicable to the host engines and operating conditions, but similar results can be expected for similar engine families, year of manufacture, and operating regimes. While the additives showed limited fuel reduction in select operation conditions, only the ethanol injection system consistently showed potential to reduce diesel fuel consumption, which may be due to its higher injection volume.

\begin{tabular}{|c|c|c|c|c|c|}
\hline \multicolumn{3}{|c|}{$\begin{array}{l}\text { 15. SUBJECT TERMS } \\
\text { Diesel } \\
\text { Diesel fuel } \\
\text { Diesel fuels_-Additives }\end{array}$} & \multicolumn{2}{|c|}{$\begin{array}{l}\text { Dredges-Motors (Diesel) } \\
\text { Energy consumption } \\
\text { Ethanol injection system } \\
\text { Fuel consumption }\end{array}$} & $\begin{array}{l}\text { Fuel usage } \\
\text { Marine diesel motors } \\
\text { Reduction }\end{array}$ \\
\hline \multicolumn{3}{|c|}{ 16. SECURITY CLASSIFICATION OF: } & \multirow{2}{*}{$\begin{array}{l}\text { 17. LIMITATION OF } \\
\text { ABSTRACT } \\
\text { UU }\end{array}$} & \multirow{2}{*}{$\begin{array}{l}\text { 18. NUMBER OF } \\
\text { PAGES } \\
36\end{array}$} & \multirow{2}{*}{\begin{tabular}{|l|}
$\begin{array}{l}\text { 19a. NAME OF RESPONSIBLE PERSON } \\
\text { Timothy Welp }\end{array}$ \\
$\begin{array}{l}\text { 19b. TELEPHONE NUMBER (Include area code) } \\
601-634-2083\end{array}$
\end{tabular}} \\
\hline $\begin{array}{l}\text { a. REPORT } \\
\text { UNLIMITED }\end{array}$ & $\begin{array}{l}\text { b. ABSTRACT } \\
\text { UNLIMITED }\end{array}$ & $\begin{array}{l}\text { c. THIS PAGE } \\
\text { UNLIMITED }\end{array}$ & & & \\
\hline
\end{tabular}

